University of Wollongong

Research Online

Faculty of Engineering and Information

Faculty of Engineering and Information

Sciences - Papers: Part A

Sciences

$1-1-2016$

\title{
A review of topologies of three-port DC-DC converters for the integration of renewable energy and energy storage system
}

Neng Zhang

University of Wollongong, nz970@uowmail.edu.au

Danny Sutanto

University of Wollongong, soetanto@uow.edu.au

Kashem M. Muttaqi

University of Wollongong, kashem@uow.edu.au

Follow this and additional works at: https://ro.uow.edu.au/eispapers

Part of the Engineering Commons, and the Science and Technology Studies Commons

Research Online is the open access institutional repository for the University of Wollongong. For further information contact the UOW Library: research-pubs@uow.edu.au 


\title{
A review of topologies of three-port DC-DC converters for the integration of renewable energy and energy storage system
}

\begin{abstract}
The application of renewable energy such as solar photovoltaic (PV), wind and fuel cells is becoming increasingly popular because of the environmental awareness and advances in technology coupled with decreasing manufacturing cost. Power electronic converters are usually used to convert the power from the renewable sources to match the load demand and grid requirement to improve the dynamic and steady-state characteristics of these green generation systems, to provide the maximum power point tracking (MPPT) control, and to integrate the energy storage system to solve the challenge of the intermittent nature of the renewable energy and the unpredictability of the load demand. In order to improve the efficiency and the power density of the overall circuit, the use of a three-port DC-DC converter, which includes a DC input port for the renewable source, a bidirectional DC input port for the energy storage system, and a DC output port for supplying the load, is a preferable solution to the traditional method using two DC-DC converters: one for the renewable sources and another for the energy storage system. In recent years, many DC-DC three-port converters have been proposed and reported in the literature. Each of these converters has its own topology and operating principle, which results in different complexities, different numbers of components, different reliability and efficiency. In this paper, a comparison of the features of different topologies of three-port DC-DC converters that have been proposed by different research groups is reviewed briefly. This review can be used as a guide for the appropriate selection of the suitable topology to meet the particular requirement of a system. The paper also discusses the potential research extension of the topologies from three-port DC-DC converters to three-port DC-AC inverters and how the voltage gain of the non-isolated three-port DC-DC converter can be improved.
\end{abstract}

\section{Keywords}

integration, renewable, energy, storage, system, three, port, dc, review, converters, topologies

\section{Disciplines}

Engineering | Science and Technology Studies

\section{Publication Details}

N. Zhang, D. Sutanto \& K. M. Muttaqi, "A review of topologies of three-port DC-DC converters for the integration of renewable energy and energy storage system," Renewable and Sustainable Energy Reviews, vol. 56, pp. 388-401, 2016. 


\title{
A Review of Topologies of Three-Port DC-DC Converters for the Integration of Renewable Energy and Energy Storage System
}

\author{
Neng Zhang, Danny Sutanto, and Kashem M. Muttaqi \\ School of Electrical, Computer and Telecommunications Engineering, University of Wollongong, New South Wales 2522, Australia
}

\begin{abstract}
The application of renewable energy such as solar photovoltaic (PV), wind and fuel cells is becoming increasingly popular because of the environmental awareness and advances in technology coupled with decreasing manufacturing cost. Power electronic converters are usually used to convert the power from the renewable sources to match the load demand and grid requirement to improve the dynamic and steady-state characteristics of these green generation systems, to provide the maximum power point tracking (MPPT) control, and to integrate the energy storage system to solve the challenge of the intermittent nature of the renewable energy and the unpredictability of the load demand. In order to improve the efficiency and the power density of the overall circuit, the use of a three-port DC-DC converter, which includes a DC input port for the renewable source, a bidirectional DC input port for the energy storage system, and a DC output port for supplying the load, is a preferable solution to the traditional method using two DC-DC converters: one for the renewable sources and another for the energy storage system. In recent years, many DC-DC three-port converters have been proposed and reported in the literature. Each of these converters has its own topology and operating principle, which results in different complexities, different numbers of components, different reliability and efficiency. In this paper, a comparison of the features of different topologies of three-port DC-DC converters that have been proposed by different research groups is reviewed briefly. This review can be used as a guide for the appropriate selection of the suitable topology to meet the particular requirement of a system. The paper also discusses the potential research extension of the topologies from three-port DC-DC converters to three-port DC-AC inverters and how the voltage gain of the non-isolated three-port DC-DC converter can be improved.
\end{abstract}

Abstract: Review, Three-Port Converters, Energy Storage, Renewable Energy

\section{Introduction}

Renewable sources such as solar photovoltaic (PV) and wind are increasingly being used because of the environmental concern and advances in the technology and rapidly decreasing manufacturing cost [1-4]. However, the intermittent nature of the renewable sources and the unpredictability of the load demand produce a challenge for the wide promotion of these clean energy sources [5-6]. Therefore, power electronic converters with energy storage systems are usually used to convert the output power from the PV panels to match the load demand, to improve the dynamic and steady-state characteristics of the green generation systems, to provide MPPT control, and to integrate the energy storage system to deal with the challenge of the intermittent nature of the renewable energy and the unpredictability of the load demand.

Traditionally, the renewable energy source is connected to the load through a traditional DC-DC converter and then the energy storage system is connected to either the input port or the output port of the traditional DC-DC converter through a bidirectional DC-DC converter for charging and discharging as shown in Fig. 1 (a) and Fig. 1 (b) [7-8]. The main disadvantage of these traditional solutions is the low efficiency due to the utilization of the additional converter for the energy storage system. Also, the multi-stage architecture may result in increased size, low power density, and relatively high cost. 


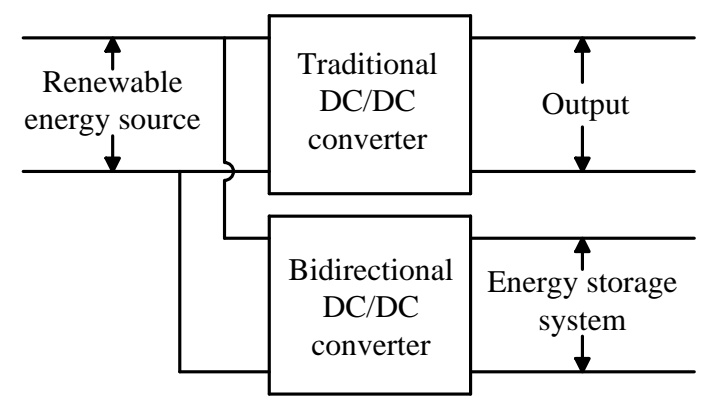

(a)

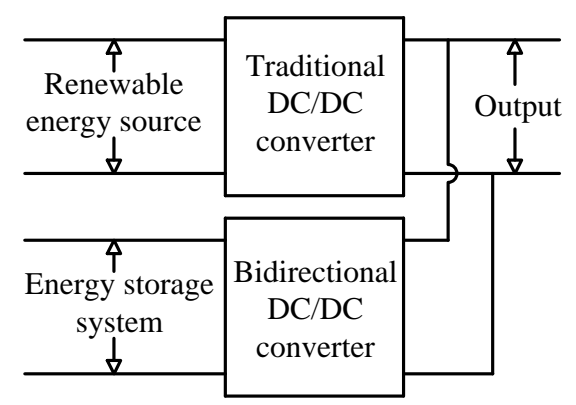

(b)

Fig. 1 Traditional power electronic systems in renewable energy system, (a) type 1, (b) type 2

A multi-input converter is a solution to satisfy the requirements of some applications that require the integration of several different types of input energy sources such as fuel cells, wind turbines, and solar PV [9]. This type of converter can be used to provide the demanded power of the load with a single stage technique; however, no energy storage system is included in these multi-input converters, and hence the system may not be able to meet the required load demand when the output power is greater than the input power. For fuel cell operation, this may happen when there is a sudden increase in load and the chemical reaction of the fuel cell is not fast enough to follow the increase in load. Similarly for solar PV application, there may be fast PV output fluctuation during passing cloud causing the PV output to be less than the load demand or when there is no sun irradiation at night. Wind power output also fluctuates with the wind speed variation.

Recently, the three-port DC-DC converters with the configuration shown in Fig. 2 have been studied to integrate the renewable energy and energy storage converters into one converter with two inputs. One three-port DC-DC converter can accept two inputs: one input is for the DC output of the PV, and the second DC input, which is a bidirectional port, is for the energy storage system for charging and discharging. The output of the three-port DC-DC converter can be connected to the DC load directly or to the grid or AC load by an inverter through a DC link capacitor. Many three-port DC-DC converters, which can satisfy the MPPT and energy-storage charging and discharging requirement, have been reported in the literature. These converters can be categorised into 3 types: non-isolated, partly-isolated, and isolated converters.

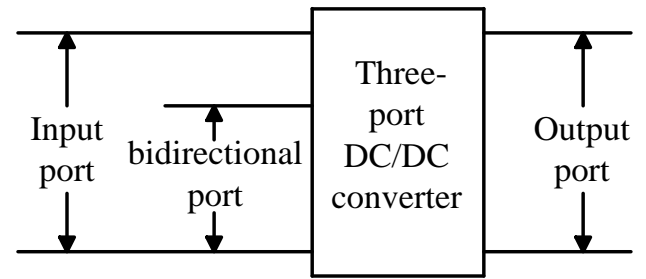

Fig. 2 The typical structure of three-port converter

Non-isolated three-port converters can result in reduced components numbers and a compact structure [10-18]. Also, a systematic method of the derivation of non-isolated three-port converters has been described in [10]. Since all of the three ports are connected directly, this type of converter can only be used in those applications where the galvanic insulation is not required [9]. Another disadvantage of the non-isolated three-port converters is that most of these converters have a limited voltage gain since the freedom of modulation of the voltage conversion ratio is only the duty cycle. Some reported papers use coupled-inductor to extend the voltage conversion ratio to overcome this issue [19-21]. Compared to the non-isolated three-port converters, partly-isolated three-port converters, which use a transformer to isolate one port from the other two common-grounded ports, can obtain higher voltage gain with a larger turn's ratio of the transformer. However, the energy storage system in these converters continues operating in all operating modes, which can shorten the lifespan of the energy system and lower the reliability of the overall system [21]. Similar to the partly-isolated converters, the isolated converters are based on the use of a high-frequency transformer, which can help them to well balance the different voltage levels among the different ports [18]. However, the number of the 
components used in this kind of converter is very large since the components are seldom shared [10]. Although both of the partly-isolated and isolated converters can be operated with soft switching on the switches using appropriate control and modulation methods, high power loss may still occur due to the leakage inductance of the transformer [21]. Also, the use of a transformer may make the converter bulky and reduce the overall power density.

This paper provides a brief review of three-port DC-DC converters proposed by different research groups in recent years and compares their features in terms of the number of components and reported efficiencies. Some potential further research topics are also discussed, including the potential application of three-port DC-AC inverters. The rest of this paper is structured as follows: Section 2 analyses the general operation principles of the three-port DC-DC converters, Section 3 presents the three-port DC-DC converters, Section 4 provides a comprehensive comparison of these converters, and Section 5 discusses some potential further research in the area. Finally, Section 6 concludes this paper.

\section{The General Operating Principles of a DC-DC Three-Port Converter}

For a traditional two-port DC-DC power electronic converter, the main function is to implement the energy conversion between the two ports. In fact, all of the multi-port DC-DC converters can be viewed as the combination of several two-port DC-DC converters and the function of these new converters is to implement a simplified topology for the energy conversion between any two of all the ports available in the converter.

The general configuration of a renewable energy generation system using a three-port DC-DC converter is shown in Fig. 3. It can be seen that the DC input port of the converter is connected to the DC output of the renewable source; the DC bidirectional port is connected to the DC energy storage system and the DC output port is connected to the DC load. In term of the power-balance principle, the relationship of the powers among the three ports can be expressed as:

$$
P_{\text {in }}+P_{b}=P_{o} \text {. }
$$

where $P_{\text {in }}$ is the DC input power, $P_{b}$ is the DC bidirectional power and $P_{o}$ is the DC output power.

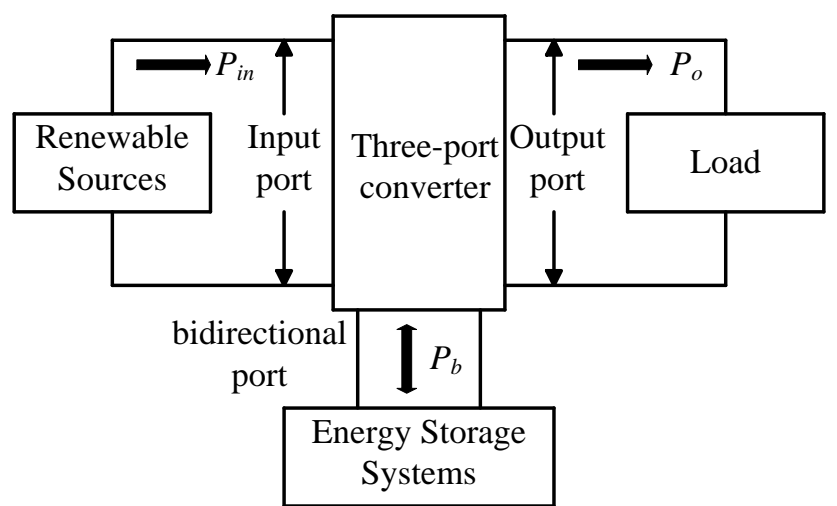

Fig. 3 The general configuration of a renewable energy generation system using a three-port converter

Since the DC input power can be either higher or lower than the DC output power (load demand), the three-port DCDC converter has three operation modes, which are described as follows:

When the DC input power is higher than the DC output power, the three-port DC-DC converter will operate under single-input dual-output (SIDO) mode, which means that only the renewable source is the input source and the energy storage system can be viewed as an additional load. The input source will supply the load alone and charge the energy storage system using the surplus power. The equivalent expression of the power flow in the converter during this operation mode is shown in Fig. 4 (a).

When the DC input power is lower than the DC output power, the three-port DC-DC converter will operate under dual-input single-output (DISO) mode, which means that the energy storage system is an additional input source. The 
energy system will be discharged to assist the input power to satisfy the load demand. The equivalent expression of the power flow in the converter during this operation mode is shown in Fig. 4 (b).

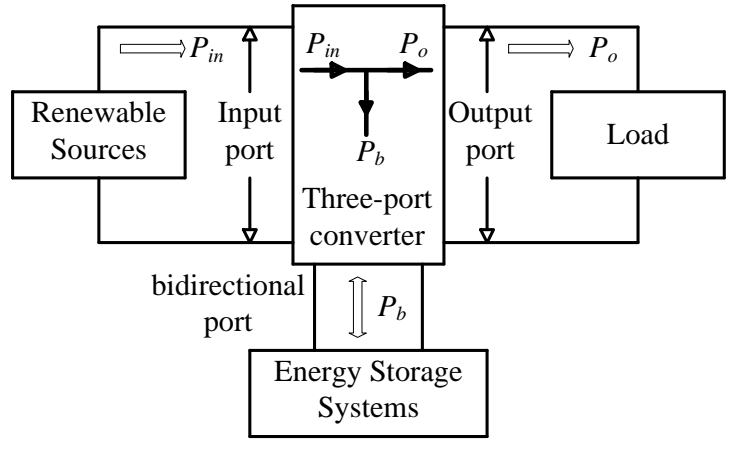

(a)

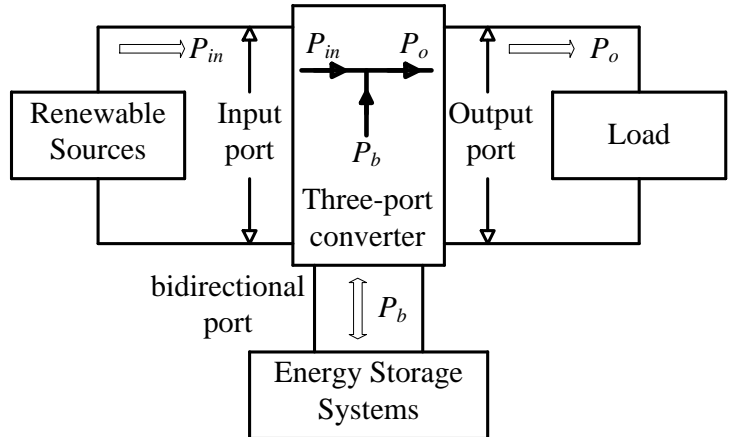

(b)

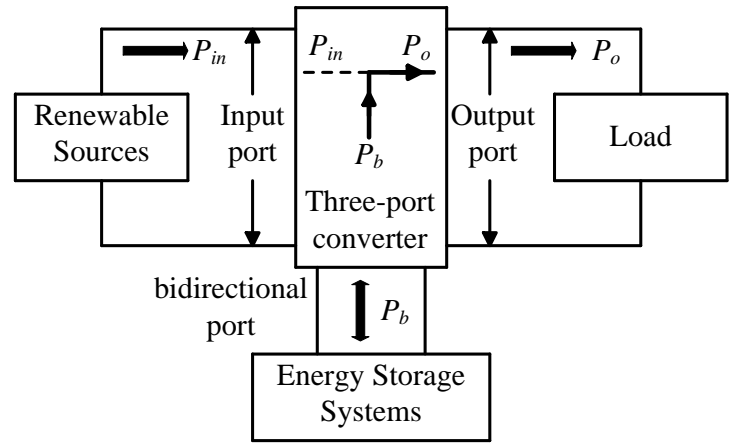

(c)

Fig. 4 The general configuration of a renewable energy generation system using a three-port converter, (a) SIDO mode, (b) DISO mode, (c) SISO mode

When the DC input power is not available or the DC input power is zero, the three-port DC-DC converter will operate under single-input single-output (SISO) mode, which is similar to the traditional DC-DC two-port converter. During this mode, the energy storage system will be discharged to supply the load alone. The equivalent expression of the power flow in the converter during this operation mode is shown in Fig. 4 (c).

\section{Reported Three-Port DC-DC converters}

As mentioned previously, many three-port DC-DC converters have been proposed recently. They have the advantages of higher efficiency and higher power density. These converters are preferable candidates for solving the issues that are produced by the intermittent nature of the renewable sources and the unpredictability of the load demand, by incorporating energy storage as an additional DC input. Depending on the connection among the three ports, this kind of converters can be classified into three types: (i) non-isolated three-port DC-DC converters, (ii) partly-isolated DC-DC three-port converters, and (iii) isolated three-port DC-DC converters, which are shown in Fig. 5. Fig. 5 (a) shows the configuration of the non-isolated three-port DC-DC converters, which shows that all of the three ports of the converter are connected directly without any galvanic isolation, which can result in small size and high power density. Fig. 5 (b) and Fig. 5 (c) show the topologies of two connecting methods of the partly-isolated converters and Fig. 5 (d) shows the configuration of the isolated three-port DC-DC converters. Both partly-isolated and isolated converters use a high-frequency transformer to implement the isolation between different ports to avoid shock hazards. Another function of the transformer is to extend the voltage conversion ratio of the converter. However, when compared with the nonisolated converters, the use of the high-frequency transformer will increase the overall size and therefore relatively reduce the power density and efficiency of the converter. Along with appropriate PWM modulation methods and power management strategies, these three types of converters can be implemented to satisfy the requirements of particular industrial applications. 


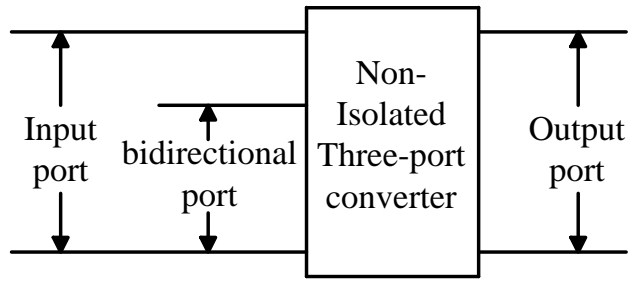

(a)

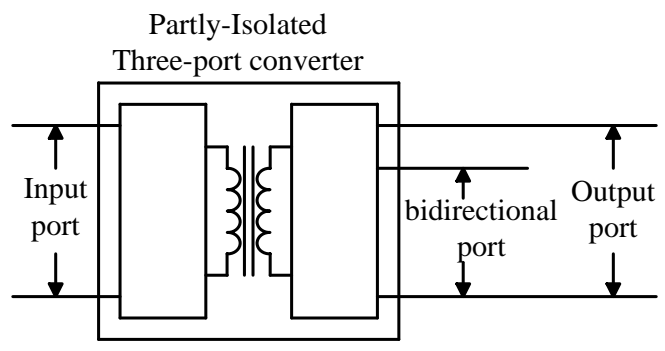

(c)

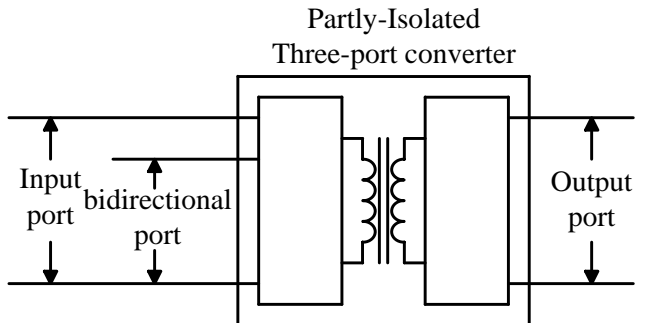

(b)

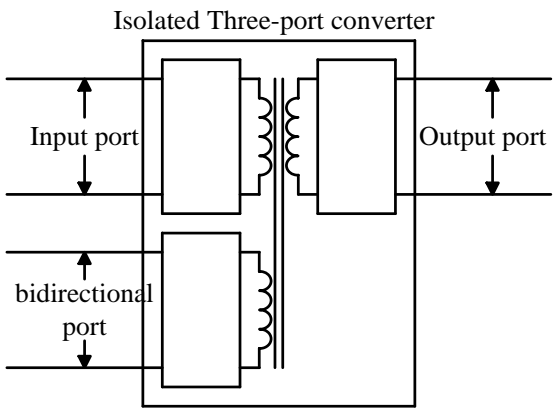

(d)

Fig. 5 The typical structure of three-port converter, (a) non-isolated, (b) partly-isolated type 1, (c) partly-isolated type 2, (d) isolated

\subsection{Non-Isolated Three-Port DC-DC Converters}

Many non-isolated three-port DC-DC converters have been presented in the literature with different control and modulation methods. Some of them use only one inductor resulting in small size and further improvement of the power density while others use two or three inductors. Since most of these converters are derived based on the traditional boost, buck, and buck-boost converters, the gain of these converters are limited. To overcome this limitation, some three-port DC-DC converters use coupled-inductors to extend the voltage conversion ratio.

A typical non-isolated converter using a single inductor, which is shown in Fig. 6, has been proposed for the solar PV application [10] - [12]. The proposed converter is derived from a dual-input converter by adding a new power flow path, which means adding a new control variable, that can be implemented using any one of the six basic DC-DC converters: boost, buck, buck-boost, cuk, sepic, and zeta converter, and can be derived systematically to obtain a family of nonisolated three-port DC-DC converters [10]. The power flow between any two of the three ports is controllable with appropriate control techniques [10].

By inserting a general cell, which is composed of a diode, a switch and an energy storage system (a battery storage in the literature), into a traditional buck-boost converter, a two-switch single-inductor three-port converter, which is shown in Fig. 7, is proposed in [13] and analysed in detail in [14]. This general cell can also be inserted into other traditional converters such as buck and boost converters to obtain new three-port converters, which has been reported in detail in [13].

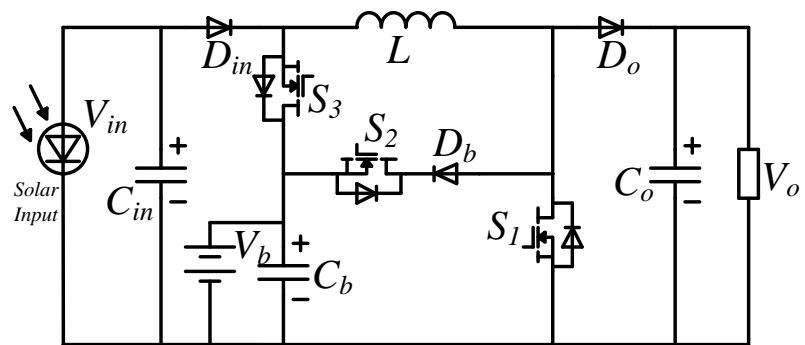

Fig. 6 The converter proposed in [10].

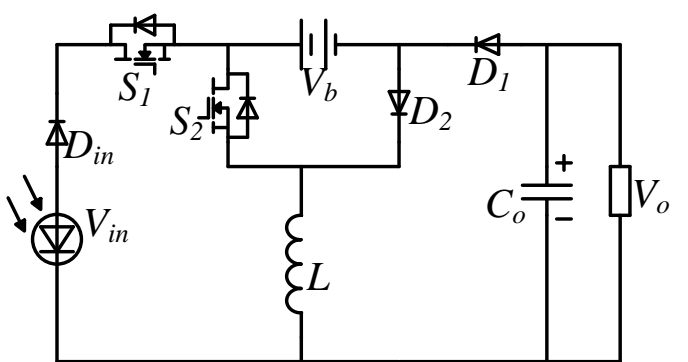

Fig. 7 The converter proposed in [13].

A novel non-isolated three-port converter is proposed in [15] by combining a traditional boost converter and a buck converter together using an additional switch as shown in Fig. 8. By decoupling the bidirectional power flow path of the 
traditional structure into two unidirectional power flow paths, a three-port DC-DC converter is proposed in [16] as shown in Fig. 9. The proposed converter can implement maximum power point tracking (MPPT) and power distribution among the three ports under the fluctuating PV input condition by applying a multi-regulator competition control technique [16]. Experimental results have been carried out to verify the operation and the applicability of this converter for stand-alone renewable power systems.

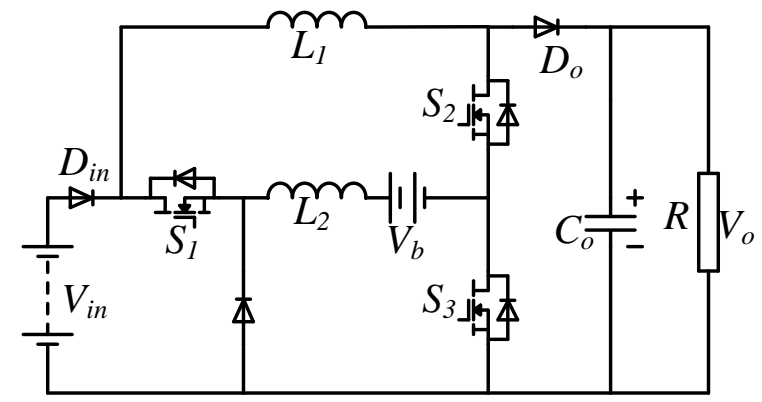

Fig. 8 The converter proposed in [15].

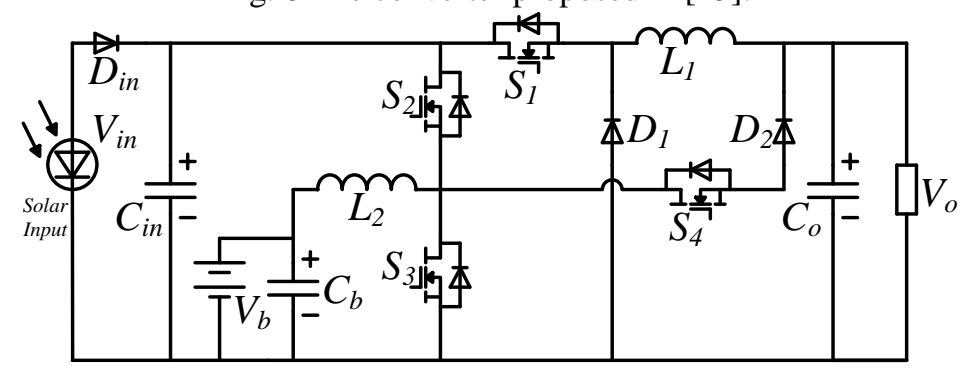

Fig. 9 The converter proposed in [16].

By combining any two of the three basic converters (buck, boost, and buck-boost converter), a family of novel twoinductor three-port DC-DC converters is proposed in [17]. These converters use only one switch to manage the power distribution among the three ports, which reduces the size and cost of the converter significantly. One of these converters is shown in Fig. 10. This converter is obtained by integrating two traditional buck converters together. The detailed analysis of this converter has been reported in [17], including the derivation of the converters and the design of the parameters. By merging a two-inductor boost converter and a two-inductor buck converter together and using an additional inductor to realize the voltage-second balance of all the inductors, a three-port converter with three switches as well as three inductors is proposed in [18] as shown in Fig. 11.

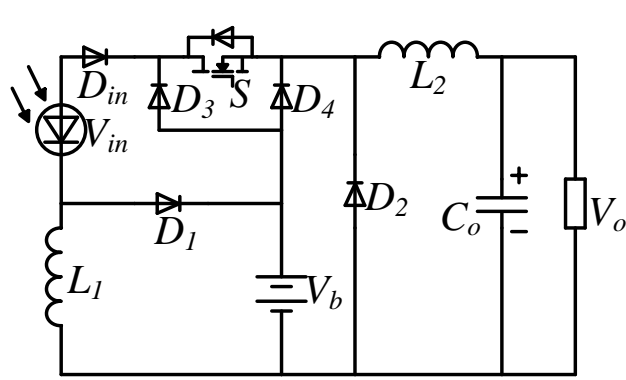

Fig. 10 The converter proposed in [17].

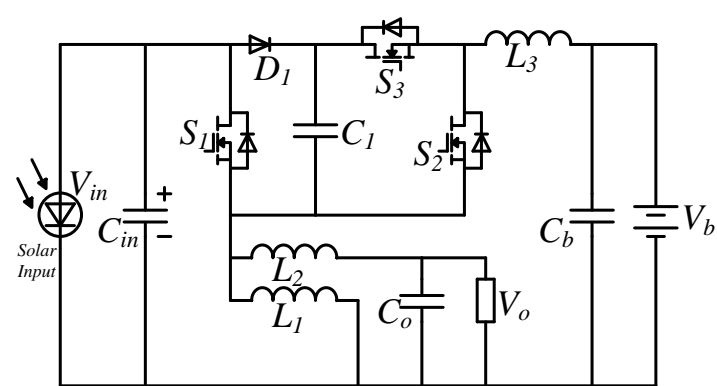

Fig. 11 The converter proposed in [18].

A new three-port DC-DC converter with a high voltage conversion ratio is proposed and analysed in [19] and [20] as shown in Fig. 12. Although the voltage gain is extended and the voltage stresses of the input side switches are reduced through the utilization of two coupled-inductors, the structure of this converter is relatively complex, since five switches are required, increasing the cost of the converter. However, one advantage of this converter is the high efficiency due to the use of active clamped circuits that can recycle the energy stored in the leakage inductors.

Based on the converter proposed in [10], a novel high step-up three-port DC-DC converter is proposed in [21] as shown in Fig. 13. By applying the coupled-inductor and switched-capacitor circuits in the output port of the converter shown in Fig. 6, the obtained converter can achieve a much higher voltage conversion ratio using a reasonable duty 
cycle and an appropriate turn ratio of the coupled-inductor when compared with the converter proposed in [10]. Therefore, the regulating freedom of the duty cycle is enlarged. Also, the voltage stresses of the switches are reduced, which can further improve the overall efficiency of the converter and can allow the use of low voltage level switches with high performances. Another high-gain three-port converter, which is shown in Fig. 14, is derived in [22] by using the multi-winding coupled-inductor, voltage-lift, and clamped-circuit techniques.

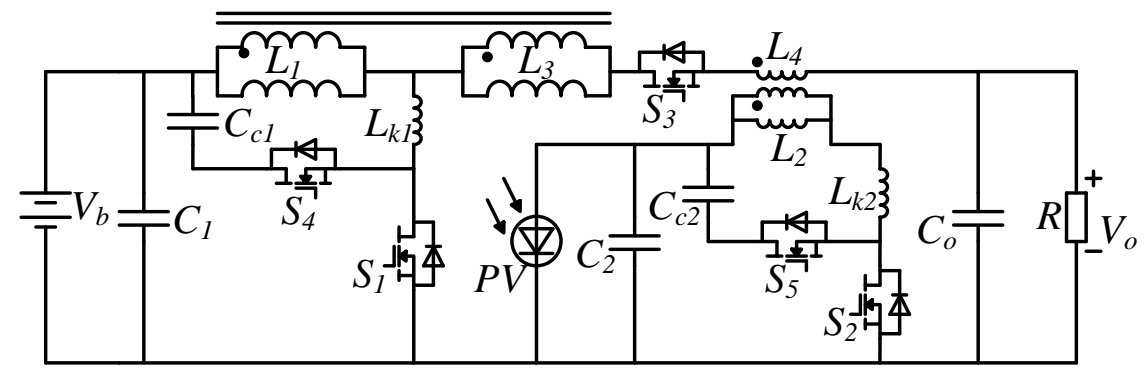

Fig. 12 The converter proposed in [19].

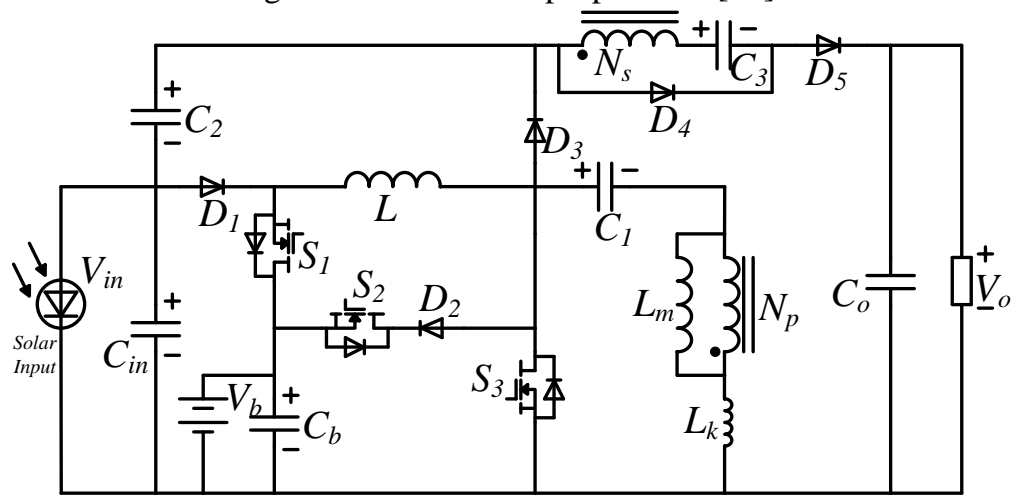

Fig. 13 The converter proposed in [21].

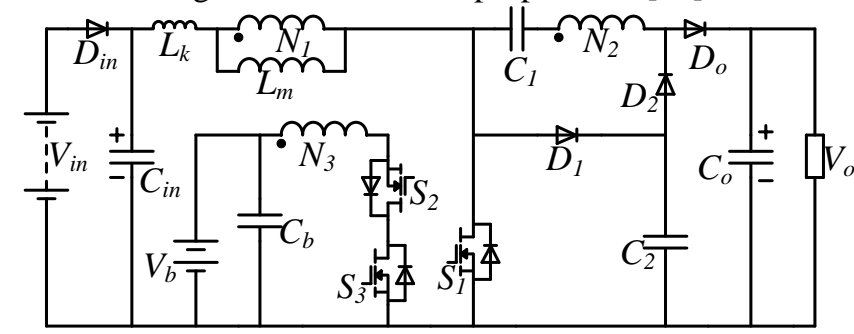

Fig. 14 The converter proposed in [22].

A three-port DC-DC converter with high voltage conversion ratio is proposed in [23], based on a unidirectional three-state switching cell as shown in Fig. 15. Due to the natural characteristics of the structure of this converter, all of the switches can operate under the soft switching condition over a wide operation range and with reduced voltage stresses, which can result in a high overall efficiency. The features such as high-gain, high efficiency and soft switching of the converter are validated by a 500W prototype in the laboratory as reported in [23].

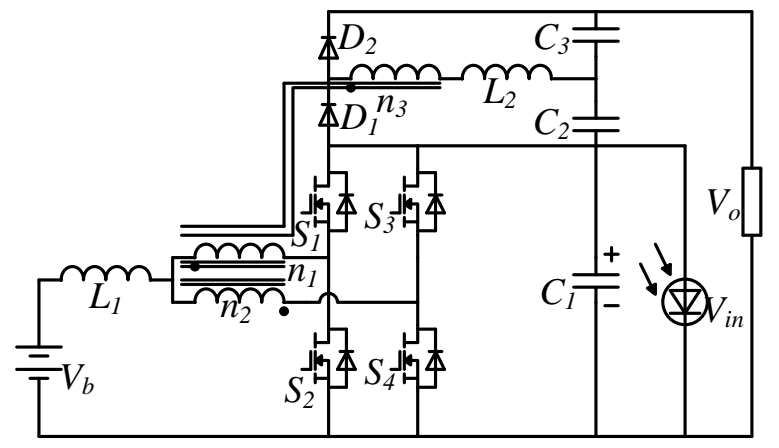

Fig. 15 The converter proposed in [23].

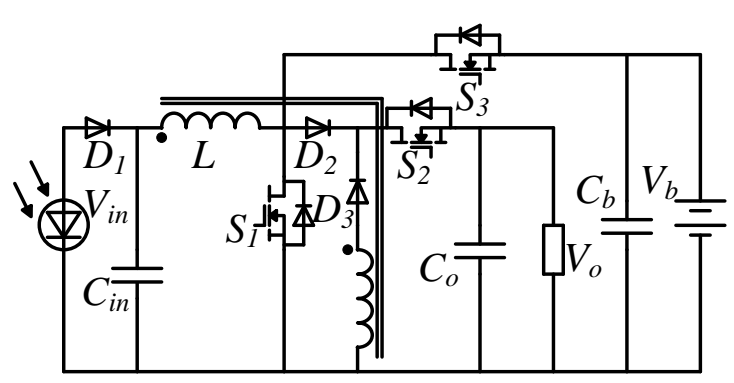

Fig. 16 The converter proposed in [24].

Based on the single-inductor dual-output converter, a novel three-port DC-DC converter is proposed in [24] as shown in Fig. 16. This converter uses a coupled-inductor and an additional switch to replace the inductor and the diode in the 
second output of the conventional single-inductor dual-output converter. With the appropriate design of the parameters and the control technique, the power flow among the three ports can be fully controlled and the converter can have a wide operation range. Although the presented converter have some advantages such as compact size and less costly, this converter can only operate under discontinuous current conducting mode, which significantly limit its practical application.

\subsection{Partly-Isolated Three-Port DC-DC Converters}

Partly-isolated three-port DC-DC converters usually have two of the three ports connected directly, and then these ports are connected to the third port with galvanic isolation. Most of these types of converters usually have the input port and the bidirectional port connected directly and then they are connected to the isolated output port as shown in Fig. 5 (b). There are also other partly-isolated three-port converters that have the output port and the bidirectional port connected without any galvanic isolation but these ports are then connected to the input port through a high frequency transformer as shown in Fig. 5 (c).

A three-port DC-DC converter based on the half-bridge converter is proposed and analysed in [25] and [26] as shown in Fig. 17. The proposed converter is derived from the traditional half-bridge converter by applying an additional switch and a diode in the primary side of the transformer and using two switches to replace the diode in the output port. All the switches in the primary side can operate under zero voltage switching for a wide range of operation conditions. The power flow among the three ports can be controlled by controlling the duty cycles of the two primary-side switches. The application of this converter has been reported in [27-29] using appropriate modulation techniques and power management strategies.

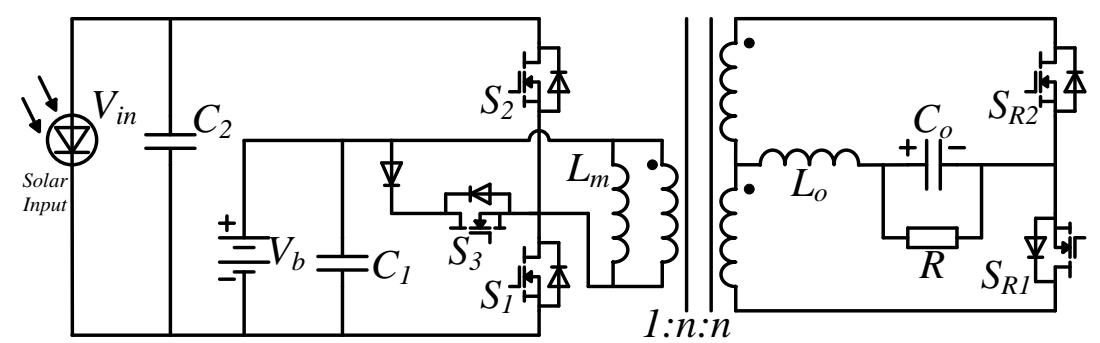

Fig. 17 The converter proposed in [25].

A novel partly-isolated three-port DC-DC converter derived from half-bridge converter is proposed in [30, 31] for a stand-alone renewable power system application as shown in Fig. 18. The proposed converter uses one of the two input dividing capacitors as the bidirectional port by allowing bias DC current in the transformer to cause the power to flow between the input port and the bidirectional port. Since there are two switches in the secondary side of the transformer for synchronous regulation, the voltage of the three ports can be regulated independently. By applying a post-regulation to replace the synchronous regulation in the converter, several other converters can be derived, which has been reported in [30]. All of the obtained converters have the advantages of reduced number of components and relatively simple configurations. The efficiency of these converters is relatively high as the power flow between any two of the three ports is in single stage. This converter has been modularized and integrated to build a DC distribution power system with a system level power management technique [32].

The traditional full-bridge converter can also be used to derive partly-isolated three-port DC-DC converters. By dividing the two switching legs of the traditional full bridge converter into two individual switching cells that can be connected to two different sources, a three-port DC-DC converter is proposed in [33] as shown in Fig. 19. Following the same concept, a family of novel three-port DC-DC converters have been derived in the same paper using a systematic method. The obtained converters have many merits such as the tight control of the power flow between any 
two of the three ports and soft-switching for all switches in the primary side of the transformer. The investigation of the performance of the converter shown in Fig. 19 for multiple energy system has been carried out in [34].

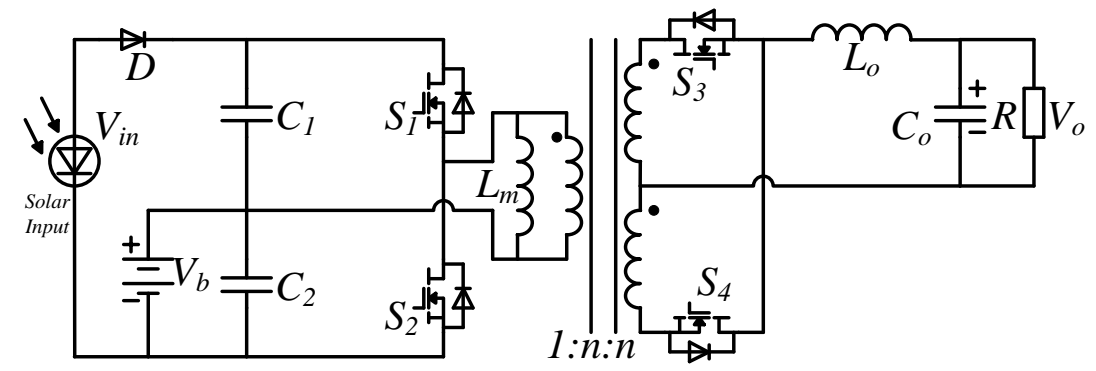

Fig. 18 The converter proposed in [30].

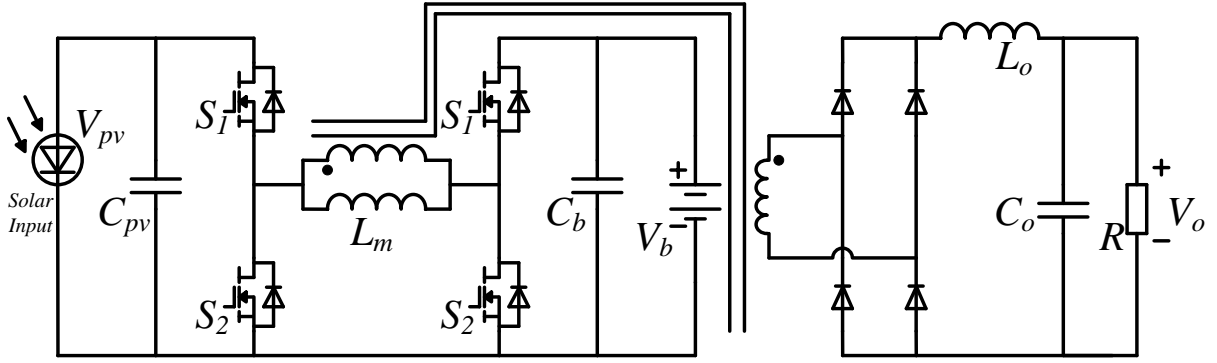

Fig. 19 The converter proposed in [33].

By combining two buck-boost converters and a full-bridge switching cell, a new three-port DC-DC converter is proposed in [35] as shown in Fig. 20. The primary side of the transformer has an interleaved structure, which can help reduce the current ripple, and the secondary side of the transformer uses a half-bridge switching cell. The power distribution among the three ports can be easily implemented using the phase-shift plus pulse width modulation method. Similar to this converter, another two converters, which have the similar structure as this converter in the primary side of the transformer but different structure in the secondary side, are presented in [36-38] as shown in Figs. 21 - 22. High efficiency can be achieved in these converters since all the switches can operate under soft-switching condition, which reduces the switching losses. Following the same concept, a three-phase three-port DC-DC converter is proposed in [39, 40] as shown in Fig. 23 for PV application in a DC distribution system.

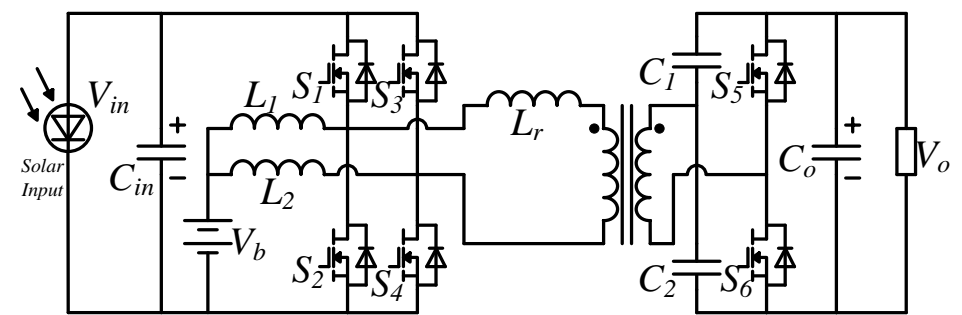

Fig. 20 The converter proposed in [35].

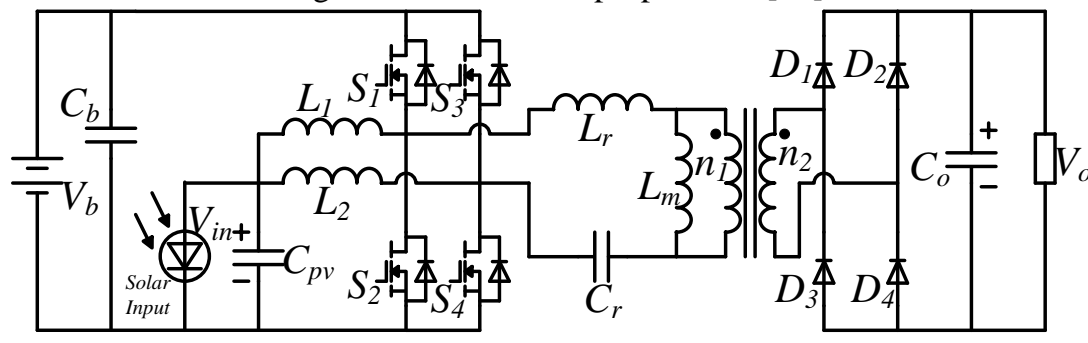

Fig. 21 The converter proposed in [36]. 


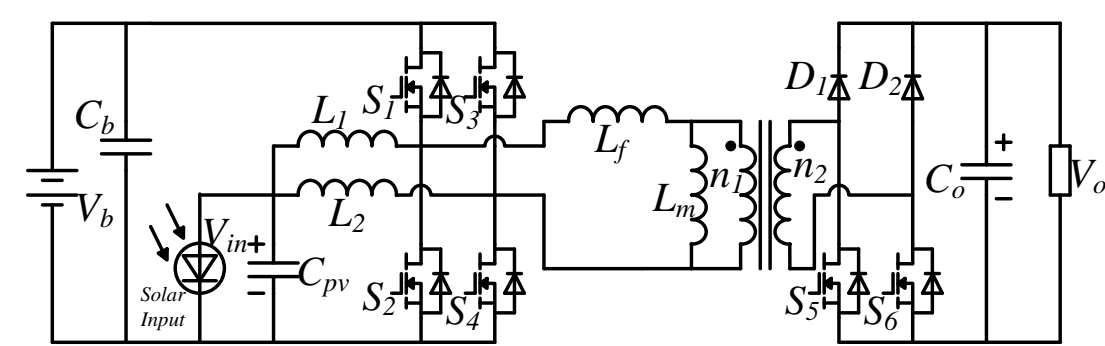

Fig. 22 The converter proposed in $[37,38]$.

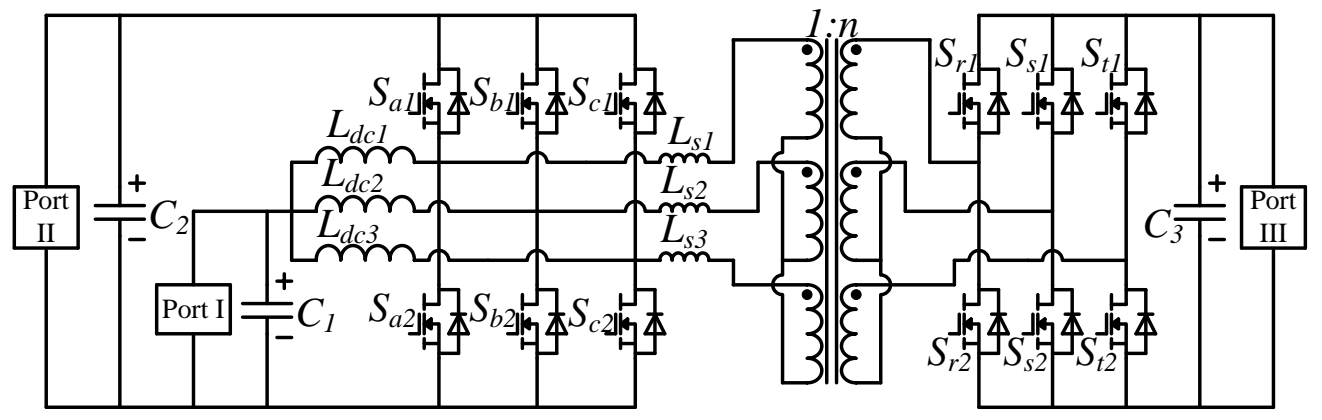

Port I: Ultra Capacitor Port 2: High-Voltage Bus Port 3: Battery

Fig. 23 The converter proposed in [39, 40].

A novel full-bridge three-port DC-DC converter has been proposed in [41] as shown in Fig. 24. The presented converter uses the magnetizing inductor of the transformer as the inductor, which reduces the number of the components as well as the size of the converter and improves the overall efficiency and power density. An inductorcapacitor-inductor (LCL) resonant circuit can be used to achieve zero-voltage and zero-current switching of the main switch for this converter is proposed in [42] as shown in Fig. 25. When the power flows from the PV to the load directly, the converter functions as a single-switch LCL resonant converter; when the power is from the PV to the battery to store the energy in the battery, the converter operates like a buck converter; and when the battery supplies the load alone, the converter can be viewed as a boost converter.

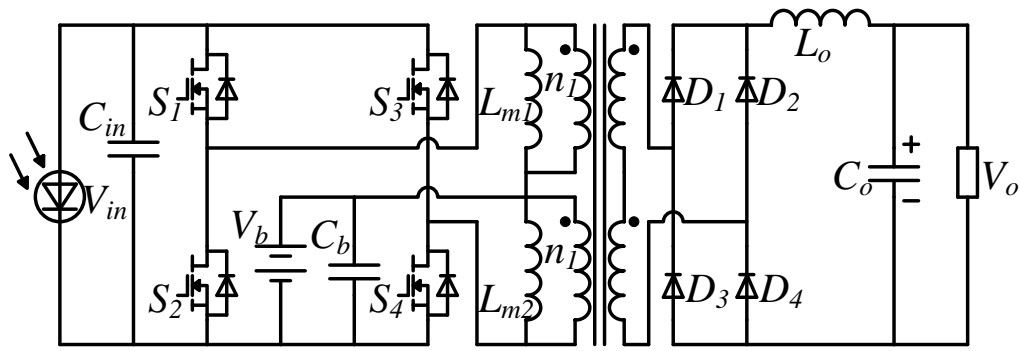

Fig. 24 The converter proposed in [41].

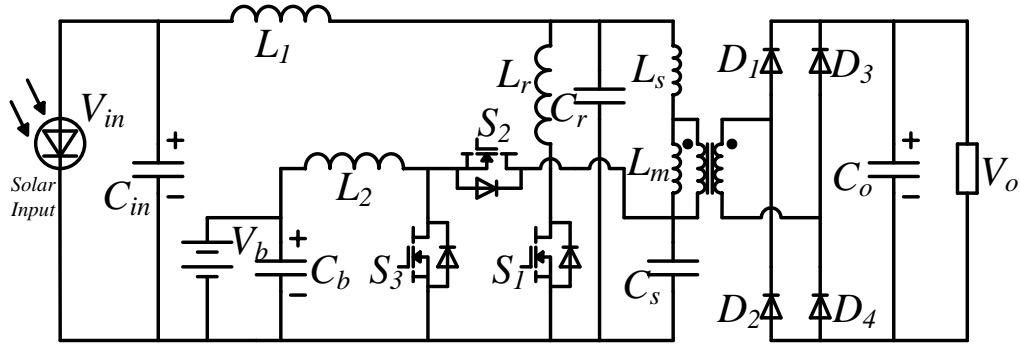

Fig. 25 The converter proposed in [42].

Based on an improved Flyback-Forward converter, a new partly-isolated three-port DC-DC converter is proposed in [43] as shown in Fig. 26 for stand-alone PV systems. When the PV supplies the load and the battery, the switches $\mathrm{S}_{1}$ and $\mathrm{S}_{2}$ operates with the same duty cycles with an $180^{\circ}$ phase displacement, while the switches $\mathrm{S}_{3}$ and $\mathrm{S}_{4}$ operate under synchronously rectifying mode. When the battery supplies the load alone, the converter functions as the traditional flyback-forward converter, which means that the switches $S_{3}$ and $S_{4}$ are the main switches, and the other two switches are used to form the active clamp circuits. When the PV charges the battery and the load is disconnected, the proposed 
converter can be viewed as two independently buck-boost converters connected in parallel. Another two partly-isolated converters, which are based on the flyback converter, are proposed in [44] and [45] as shown in Fig. 27 and Fig. 28, respectively.

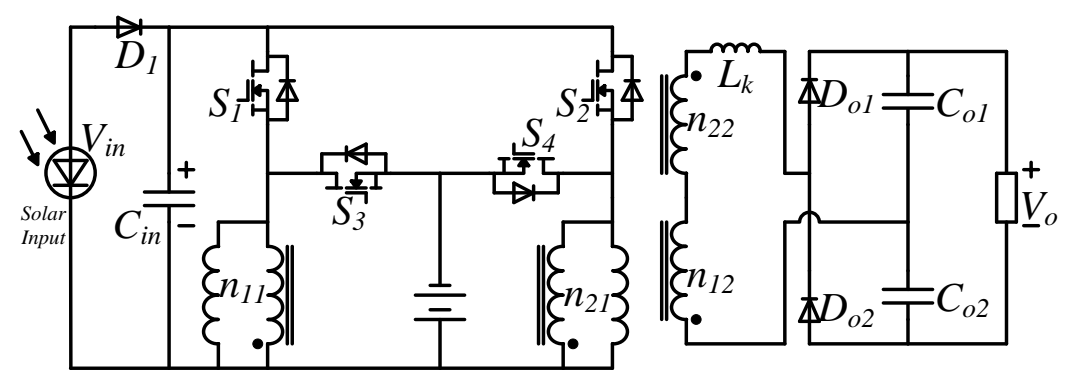

Fig. 26 The converter proposed in [43].

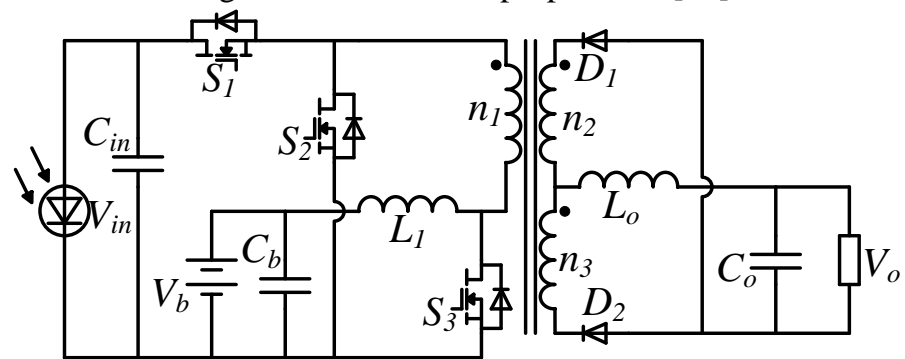

Fig. 27 The converter proposed in [44].

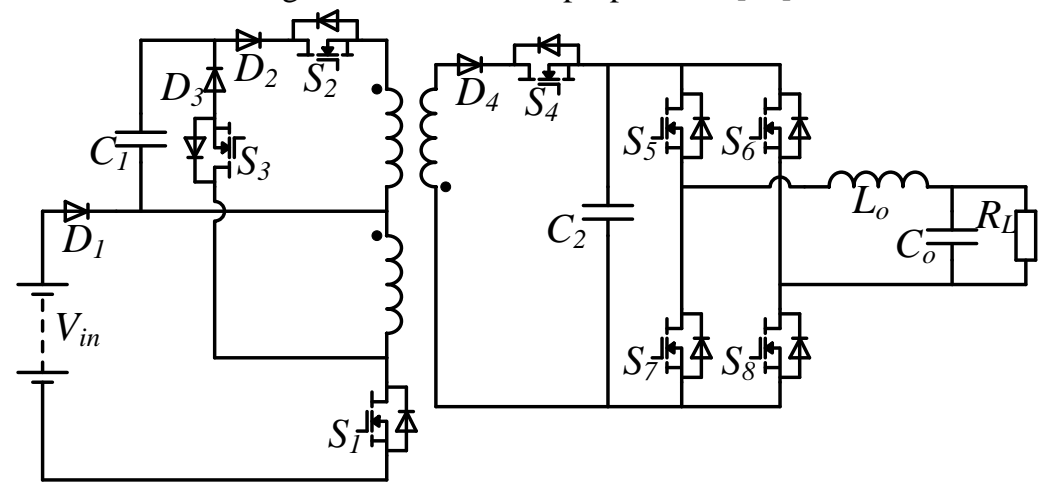

Fig. 28 The converter proposed in [45].

Different from the above presented converters, which integrate the input port and the bidirectional port to the primary side of the high-frequency transformer, a novel partly-isolated converter, which integrates the bidirectional port and the load to the secondary side of the transformer and the PV is isolated at the primary side of the transformer, is proposed in [46] as shown in Fig. 29. The detailed derivation of the proposed converter from the traditional half-bridge converter is introduced in [46]. The output circuit of the traditional half-bridge converter is detached first and then a boost converter is inserted between the two detached outputs to provide the power flow path between the battery and the load; finally a boost converter is applied in the input port to minimize the ripples of the input current. All the switches in this converter can work under zero current switching condition to reduce the switching losses to improve the overall efficiency of the converter.

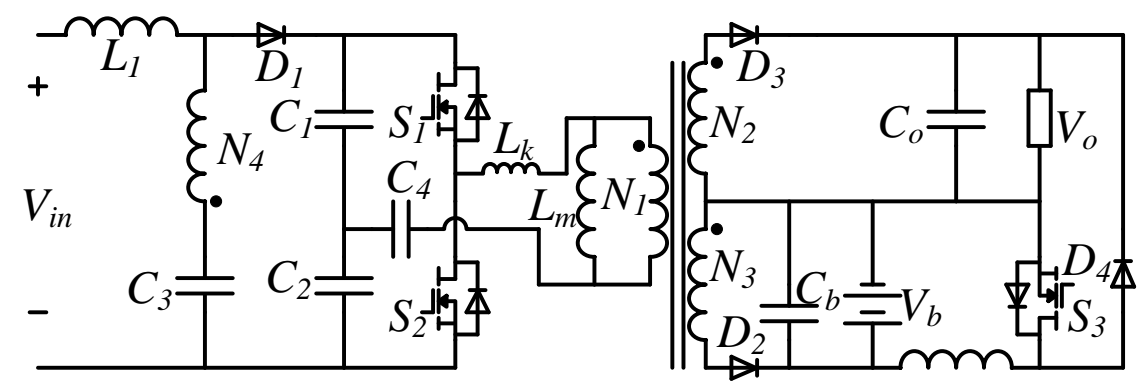

Fig. 29 The converter proposed in [46]. 


\subsection{Isolated Three-Port DC-DC Converters}

In isolated three-port DC-DC converters, the power flow between any two of the three-ports is realized through a multiple-winding high-frequency transformer. Therefore, this type of converters has good galvanic isolation and all of the three ports have their own components. In fact, most of the isolated converters are based on the traditional fullbridge converters or half-bridge converters or the combination of them for energy transformation.

An isolated three-port DC-DC converter based on the combination of a three full-bridge structure and a threewinding transformer, as shown in Fig. 30, is first proposed in [47]. Although it was proposed for the hybrid fuel cell system application, it can be used in other renewable energy applications such as PV generation systems. After the introduction of this converter, it has gained a lot of attention from other researchers, in terms of the analysis of the performances of the converter, the control methods, the loss evaluations, and its applications [48-54]. In order to reduce the ripples of the input current, an inductor has been added between the input source and the full-bridge structure in the input port as shown in Fig. 31 [55]. A new full-bridge based three-port DC-DC converter as shown in Fig. 32 is reported in [56, 57]. Compared to the converter shown in Fig. 30, this converter includes two additional series resonant circuit in the primary side of the transformer, to implement the soft switching of the switches to reduce the switching losses. Another benefit of this converter over the previous one is that this converter can operate with a high switching frequency with realizable component values.

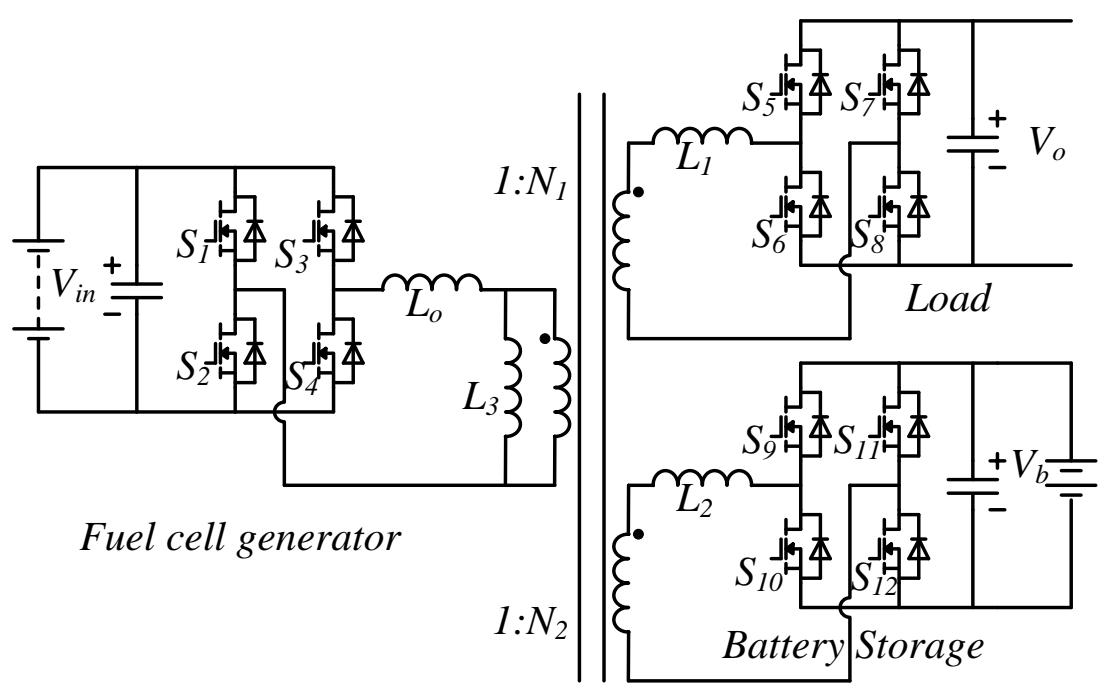

Fig. 30 The converter proposed in [47].

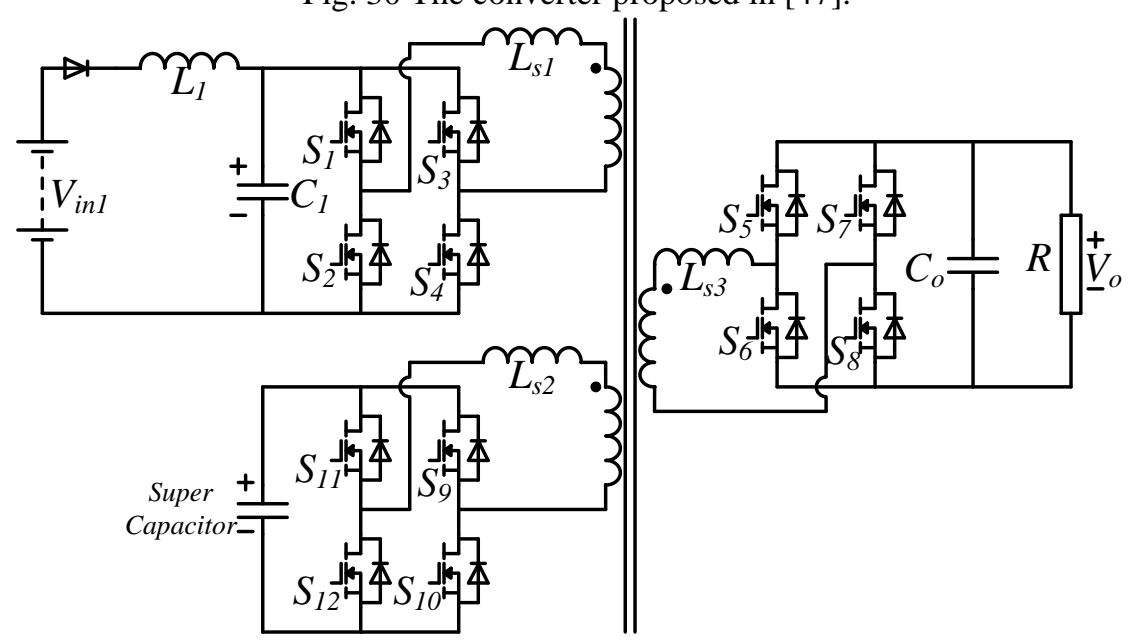

Fig. 31 The converter reported in [48].

By using three half-bridge structures to replace the full-bridge structures in the converter shown in Fig. 30, a new three-port DC-DC converter, which is shown in Fig. 33, has been proposed in [58]. It should be noted that one of the three half-bridge circuits in this converter is a boost half-bridge converter, which is used to connect the bidirectional 
port for charging and discharging of the energy storage system. Adding an inductor in the input port to reduce the ripples of the input current has been analysed in [59] as shown in Fig. 34. The full-bridge circuit and half-bridge circuit can also be combined to implement an isolated three-port DC-DC converter as reported in [60]. The obtained converter is shown in Fig. 35.

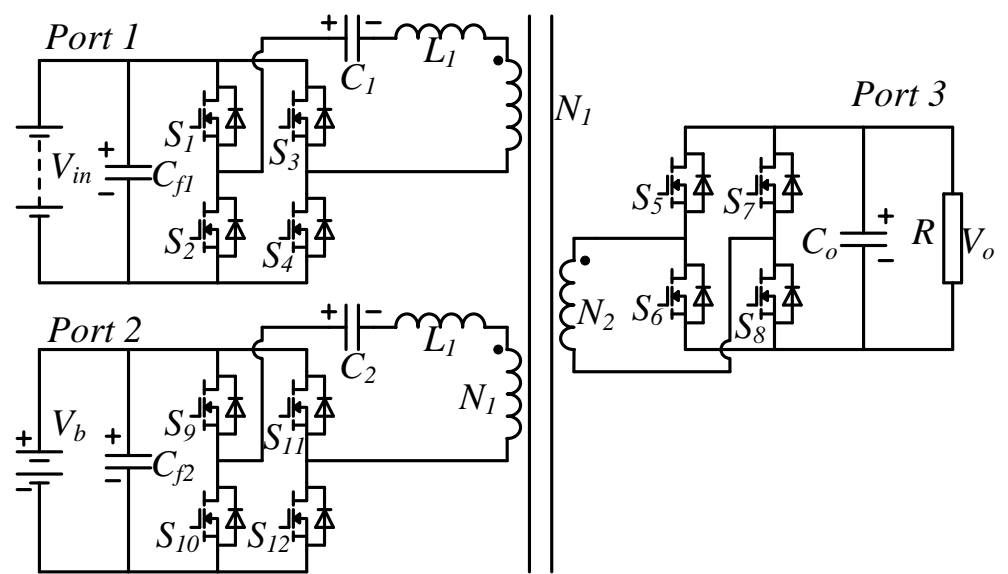

Fig. 32 The converter proposed in [56].

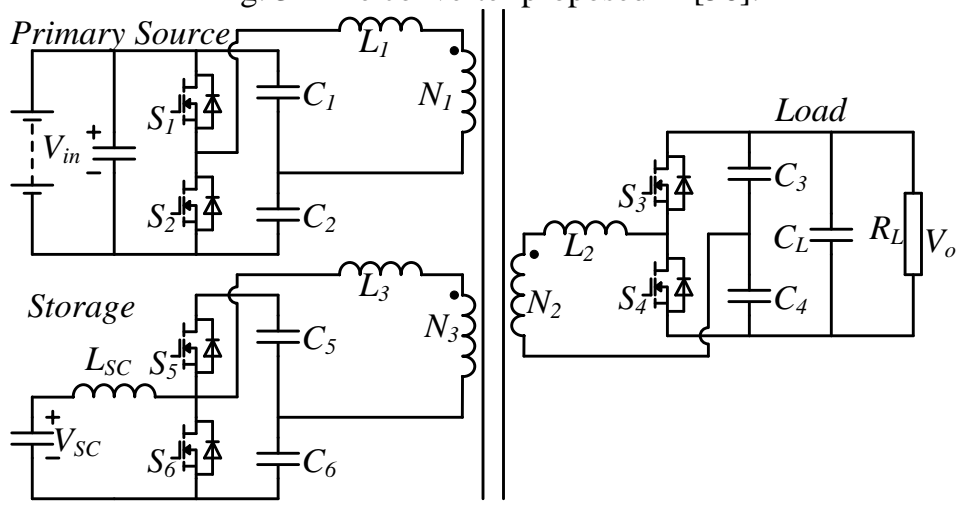

Fig. 33 The converter proposed in [58].

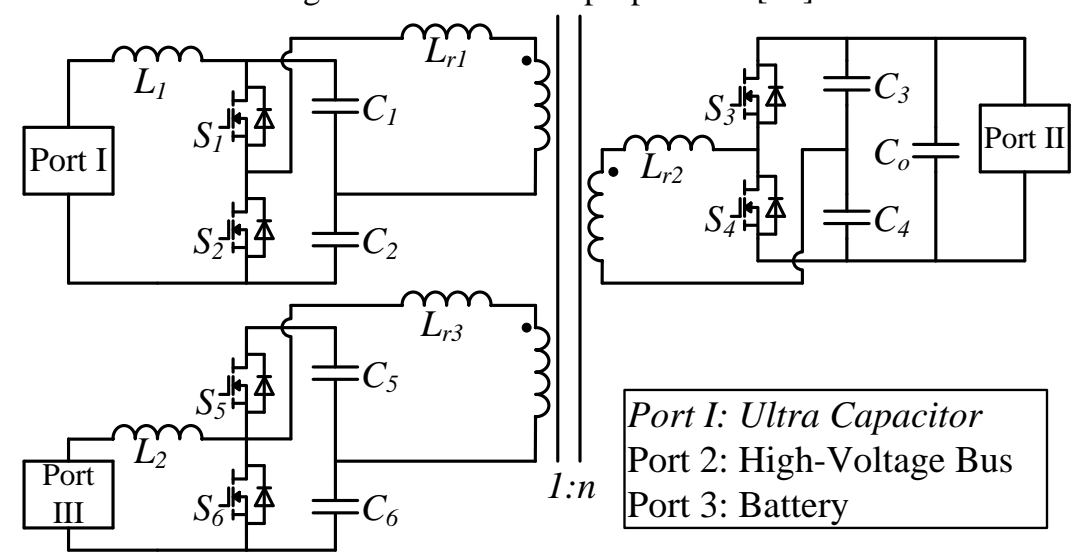

Fig. 34 The converter proposed in [59].

Based on using two current-fed switching networks and two multi-resonant circuits as the input port and the bidirectional port respectively and using a full-bridge diode rectifier as the output port, a novel isolated three-port DCDC converter is proposed in [61] as shown in Fig. 36. Compared to the above isolated converters, this converter only requires four switches, which reduces the cost of the converter. Also, the current ripples of the converter are very low due to the utilisation of inductors in all of the three ports.

Apart from using the half-bridge and full-bridge configurations, converters with other configurations can also be used to form three-port converters. Based on the traditional Cuk converter, a novel isolated three-port DC-DC converter, which uses only three switches, has been reported in [62]. This converter integrates three Cuk converters through the application of a three-winding transformer as shown in Fig. 37. 


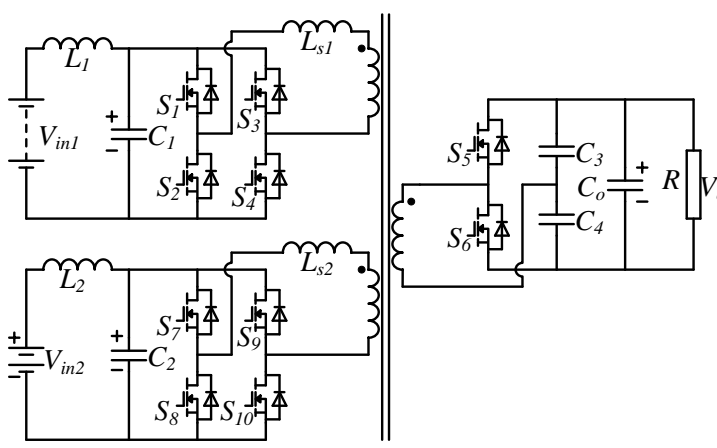

Fig. 35 The converter proposed in [60].

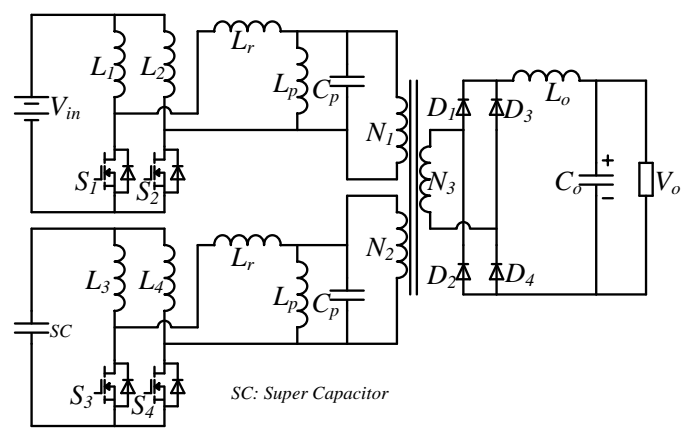

Fig. 36 The converter proposed in [61].

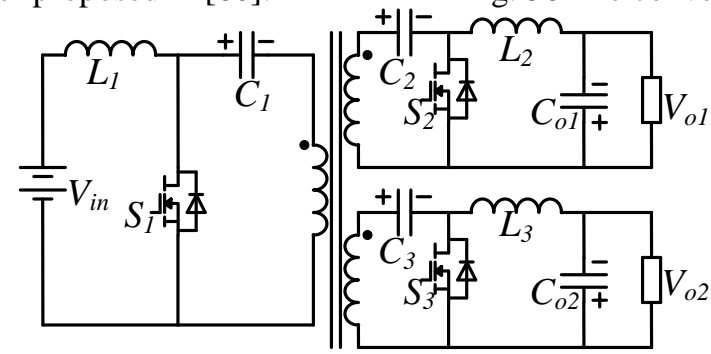

Fig. 37 The converter proposed in [62].

\section{Comparison of three-port converters}

The main purpose of these novel topologies of three-port DC-DC converters is to address the intermittent nature of the renewable sources by energy storage and using only one DC-DC converter with two input sources. Although there are many three-port DC-DC converters that have been proposed in the past decade, they have different advantages and disadvantages. In order to provide some guides for the selection of the three-port converter for practical applications, a comparison in terms of components number, capacity, and efficiency of these converters is provided in Table 1.

Apart from the cost of the control circuits, the non-isolated three-port converters can generally result in lower cost than the partly-isolated and isolated converters since they usually use less power switching devices and require fewer components. Also, the need to use a high-frequency transformer can further increase of the cost of the partly-isolated and isolated three-port converters. Among the non-isolated converters, the topologies with high voltage gain are more costly than the other converters due to the use of a coupled-inductor.

Reliability is a crucial factor to evaluate the performance of the converters [63, 64]. For all converters, the reliability will decrease with the progress of the operation time in consideration. On the component-level, the more switches the converter uses; the lower is the reliability the converter. Therefore, the non-isolated and partly-isolated converters have relatively higher reliability than the isolated converters.

Although all of the reviewed three-port converters are capable of the function of MPPT control, and can provide the required load demand with the help of the energy storage system, there are some limitations to the application of the converters due to their unique configuration. The non-isolated converters are good candidates for small power applications such as portable products, but not applicable in the applications that require strict galvanic isolation, where partly-isolated and isolated three-port converters are better choices. 
Table 1 Comparison of three-port converters (NA: Not Available)

\begin{tabular}{|c|c|c|c|c|c|c|c|}
\hline $\begin{array}{l}\text { Structure } \\
\text { of the } \\
\text { converter }\end{array}$ & $\begin{array}{c}\text { Number of } \\
\text { semiconductors }\end{array}$ & Number of inductors & $\begin{array}{l}\text { Number of } \\
\text { windings of the } \\
\text { transformer }\end{array}$ & $\begin{array}{l}\text { Reported } \\
\text { capacity }\end{array}$ & $\begin{array}{c}\text { Reported } \\
\text { maximum } \\
\text { efficiencies }\end{array}$ & Features & References \\
\hline \multirow{11}{*}{$\begin{array}{l}\text { Non- } \\
\text { Isolated }\end{array}$} & $\begin{array}{l}3 \text { switches, } 3 \\
\text { diodes }\end{array}$ & 1 & NA & $1 \mathrm{KW}$ & $97.2 \%$ & $\begin{array}{l}\text { Small size; } \\
\text { High integration; } \\
\text { High efficiency; } \\
\text { High power density }\end{array}$ & [10 - 12] \\
\hline & $\begin{array}{c}2 \text { switches, } 2 \\
\text { diodes }\end{array}$ & 1 & NA & $24 \mathrm{~W}$ & - & $\begin{array}{c}\text { Easy to derivation; } \\
\text { Compact size; } \\
\text { Maximum usage of the control variable }\end{array}$ & {$[13,14]$} \\
\hline & $\begin{array}{c}3 \text { switches, } 3 \\
\text { diodes }\end{array}$ & 2 & NA & $100 \mathrm{~W}$ & - & $\begin{array}{l}\text { Simple operation; } \\
\text { Easy to control }\end{array}$ & [15] \\
\hline & $\begin{array}{c}4 \text { switches, } 3 \\
\text { diodes }\end{array}$ & 2 & NA & $400 \mathrm{~W}$ & $92 \%$ & $\begin{array}{c}\text { Higher power density; } \\
\text { High reliability }\end{array}$ & {$[16]$} \\
\hline & $\begin{array}{c}1 \text { switches, } 5 \\
\text { diodes }\end{array}$ & 2 & NA & $24 \mathrm{~W}$ & - & $\begin{array}{l}\text { Only one switch; } \\
\text { Small size; } \\
\text { Long lifespan of the battery; } \\
\text { Cost efficient }\end{array}$ & [17] \\
\hline & $\begin{array}{l}3 \text { switches, } 1 \\
\text { diodes }\end{array}$ & 3 & NA & $1.2 \mathrm{KW}$ & $93.5 \%$ & $\begin{array}{c}\text { High integration; } \\
\text { High efficiency; } \\
\text { Continuous current in all of the three ports; } \\
\text { Reduced electromagnetic noise }\end{array}$ & [18] \\
\hline & 5 switches & 2 Coupled- inductors & NA & $200 \mathrm{~W}$ & $90.1 \%$ & $\begin{array}{c}\text { High voltage gain; } \\
\text { Output voltage is always regulated at } 380 \mathrm{~V} \text { under all } \\
\text { operation modes }\end{array}$ & {$[19,20]$} \\
\hline & $\begin{array}{c}3 \text { switches, } 5 \\
\text { diodes }\end{array}$ & 1, 1 Coupled-inductor & NA & $300 \mathrm{~W}$ & $94 \%$ & $\begin{array}{c}\text { Reduced volume; } \\
\text { High voltage conversion ratio; } \\
\text { Large degree pf freedom of the duty cycle; } \\
\text { Low voltage stresses of the switches; } \\
\text { High efficiency } \\
\end{array}$ & {$[21]$} \\
\hline & $\begin{array}{c}3 \text { switches, } 4 \\
\text { diodes }\end{array}$ & 1 Coupled-inductor & NA & $250 \mathrm{~W}$ & $94 \%$ & $\begin{array}{l}\text { High voltage step-up; } \\
\text { High efficiency }\end{array}$ & {$[22]$} \\
\hline & $\begin{array}{c}4 \text { switches, } 2 \\
\text { diodes }\end{array}$ & 2, 1 Coupled-inductor & NA & $500 \mathrm{~W}$ & $96.09 \%$ & $\begin{array}{c}\text { High voltage gain; } \\
\text { ZVS operation over a wide range of the duty cycle; } \\
\text { High efficiency; } \\
\text { Reduced voltage stresses of the main switches; } \\
\text { Reduced dimensions of the magnetic elements }\end{array}$ & [23] \\
\hline & $\begin{array}{c}3 \text { switches, } 3 \\
\text { diodes }\end{array}$ & 1 Coupled-inductor & NA & - & - & $\begin{array}{l}\text { Compact size; } \\
\text { Cost efficient; } \\
\text { All of the three-ports are common-ground; }\end{array}$ & {$[24]$} \\
\hline
\end{tabular}




\begin{tabular}{|c|c|c|c|c|c|c|c|}
\hline \multirow{13}{*}{$\begin{array}{l}\text { Partly- } \\
\text { Isolated }\end{array}$} & $\begin{array}{c}5 \text { switches, } 1 \\
\text { diodes }\end{array}$ & 1 Transformer & 3 & $200 \mathrm{~W}$ & - & $\begin{array}{c}\text { ZVS for all primary side switches over a wide range of } \\
\text { conditions; } \\
\text { Tight load regulation }\end{array}$ & [25 - 29] \\
\hline & $\begin{array}{c}4 \text { switches, } 1 \\
\text { diodes }\end{array}$ & 1 Transformer & 3 & $120 \mathrm{~W}$ & - & $\begin{array}{c}\text { Simple topology; } \\
\text { High integration; } \\
\text { Reduced number of devices; } \\
\text { ZVS of most of the switches }\end{array}$ & {$[30-32]$} \\
\hline & $\begin{array}{c}\text { switches, } 4 \\
\text { diodes }\end{array}$ & 1 Transformer & 2 & $180 \mathrm{~W}$ & $94 \%$ & $\begin{array}{l}\text { ZVS for all of the primary-side switches; } \\
\text { Operating over a large voltage range }\end{array}$ & {$[33,34]$} \\
\hline & 6 switches & 2, 1 Transformer & 2 & $300 \mathrm{~W}$ & - & $\begin{array}{l}\text { Minimized input current ripples; } \\
\text { Bidirectional power flow between any two ports; } \\
\text { Soft switching of all switches }\end{array}$ & [35] \\
\hline & $\begin{array}{c}4 \text { switches, } 4 \\
\text { diodes }\end{array}$ & 2, 1 Transformer & 2 & $500 \mathrm{~W}$ & - & $\begin{array}{l}\text { Cost efficient; } \\
\text { ZVS for all of the primary-side switches; } \\
\text { ZCS for all of the secondary-side diodes; } \\
\text { Reduced switching losses; } \\
\text { Small input current ripples }\end{array}$ & [36] \\
\hline & $\begin{array}{c}6 \text { switches, } 2 \\
\text { diodes }\end{array}$ & 2, 1 Transformer & 2 & $800 \mathrm{~W}$ & $92 \%$ & $\begin{array}{l}\text { ZVS for all of the switches; } \\
\text { High power density; } \\
\text { High efficiency }\end{array}$ & {$[37,38]$} \\
\hline & 12 switches & 3, 1 Transformer & 6 & $3 \mathrm{KW}$ & - & $\begin{array}{c}\text { Small input current ripples; } \\
\text { Three-phase configuration; } \\
\text { ZVS in all operation modes and conditions; } \\
\text { Control of the power flow is naturally decoupled }\end{array}$ & {$[39,40]$} \\
\hline & $\begin{array}{c}4 \text { switches, } 4 \\
\text { diodes }\end{array}$ & 1, 2 Transformer & 2 & $400 \mathrm{~W}$ & $93 \%$ & $\begin{array}{l}\text { ZVS for all of the primary side switches; } \\
\text { Reduced number of devices }\end{array}$ & {$[41]$} \\
\hline & $\begin{array}{l}3 \text { switches, } 4 \\
\text { diodes }\end{array}$ & 3, 1 Transformer & 2 & $50 \mathrm{~W}$ & - & $\begin{array}{l}\text { ZVS and ZCS for the main switches; } \\
\text { Reduced number of the switches }\end{array}$ & {$[42]$} \\
\hline & $\begin{array}{c}4 \text { switches, } 3 \\
\text { diodes }\end{array}$ & 2 Transformer & 2 & $250 \mathrm{~W}$ & $91.3 \%$ & $\begin{array}{l}\text { High step up voltage conversion ratio; } \\
\text { Relatively simple structure; } \\
\text { Cost effective } \\
\end{array}$ & [43] \\
\hline & $\begin{array}{c}3 \text { switches, } 2 \\
\text { diodes }\end{array}$ & 2, 1 Transformer & 3 & $50 \mathrm{~W}$ & - & ZVS for all of the switches & [44] \\
\hline & $\begin{array}{l}4 \text { switches, } 4 \\
\text { diodes }\end{array}$ & 1 Transformer & 3 & $95 \mathrm{~W}$ & - & Eliminated low frequency current ripples & {$[45]$} \\
\hline & $\begin{array}{c}3 \text { switches, } 4 \\
\text { diodes }\end{array}$ & 2, 1 Transformer & 4 & $500 \mathrm{~W}$ & $94 \%$ & $\begin{array}{l}\text { ZCS for all the main diodes and switches; } \\
\text { Continuous input current; } \\
\text { Easy for modularizing in parallel }\end{array}$ & [46] \\
\hline Isolated & 12 switches & 1 Transformer & 3 & $1.5 \mathrm{KW}$ & $91.7 \%$ & $\begin{array}{l}\text { High voltage conversion ratios; } \\
\text { Galvanic isolation for all of the three ports }\end{array}$ & {$[47-54]$} \\
\hline
\end{tabular}




\section{Direction of Future Research}

Although the research of three-port DC-DC converters has made tremendous improvement during recent years, however, the applications of these three-port DC-DC converters have given rise to some issues such as the limitation of the voltage conversion ratio of the non-isolated three-port converters and the requirement for an additional inverter for AC applications. Three research topics that can be considered for future work are presented in the following subsections.

\subsection{High-gain non-isolated three-port converters}

When the three-port DC-DC converter is used in the grid-connected renewable energy generation systems, such as wind systems and distributed photovoltaic generation systems, the voltage conversion ratio, $V_{\text {out }} / V_{\text {in }}$ (where $V_{\text {out }}$ is the output voltage and $V_{\text {in }}$ is the input voltage) needs to be relatively high. However, the conventional non-isolated threeport DC-DC converters cannot be used to realise such a high step-up gain. Fortunately, there are many techniques, which can be applied to extend the voltage gain of the traditional two-port DC-DC converter that have been reported in the literature [65], such as using coupled inductors, switched-capacitors, switched-inductors, and voltage multiplier circuits. The application of these techniques can also be extended to the three-port DC-DC converters to implement the high voltage conversion ratio. It is also reported in the literature that the utilization of coupled inductors is relatively better than using the transformers, since the winding structure of the coupled inductors is simpler and the conduction losses is less [66]. Although some work about this research topic has been carried out by a small group of researchers, most of them have used the same technique, which is the coupled-inductor circuit [19-24]. Therefore, some work can be conducted in developing new non-isolated three-port DC-DC converters with high voltage gain using the voltage gain extension cells that have been successfully applied in the two-port DC-DC converters.

\subsection{Three-port inverters}

There are two types of configurations which are used to convert the power from renewable energy source to the grid, either using a double-stage connection, which includes three topologies as shown in Fig. 38, or a single-stage as shown in Fig. 39. Traditionally, the double-stage connection requires two conventional DC-DC converters as well as a DC-AC inverter as shown in Fig. 38 (a) and Fig. 38 (b). These two types of topologies are of big size, high cost and low efficiency due to the application of three converters. With the development of three-port converters, a novel doublestage configuration can be adopted as shown in Fig. 38 (c). However, this configuration still requires two converters. The single-stage connection has the benefit of having a higher efficiency and a lower cost compared to those of the double-stage connection. Therefore, the concept of three-port DC-DC converters can be enhanced by implementing a DC-AC three-port inverter, which includes a DC input port for interfacing the renewable source, another DC port for the connection of an energy storage system and an AC output port for supplying the grid or other AC loads directly. Recently, a few works in this field has been carried out based on the traditional three-level neutral-point-clamped inverter as shown in Fig. 40 and Fig. 41 [67, 68]. Simulation and experimental results in [67, 68] have demonstrated the validity of the concept. Following the development of the three-port DC-DC converters, there are many research opportunities to design novel three-port DC-AC inverters based on the traditional single-phase and three-phase inverters. 


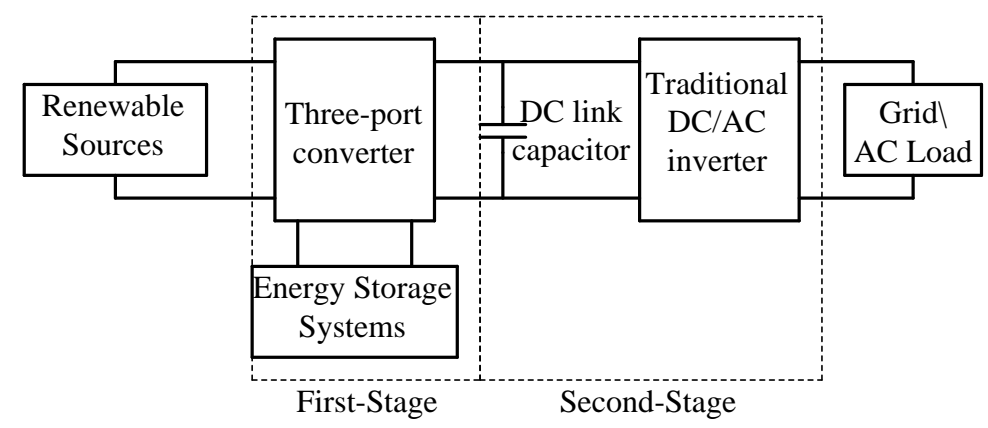

(c)

Fig. 38 The configuration of double-stage connection.

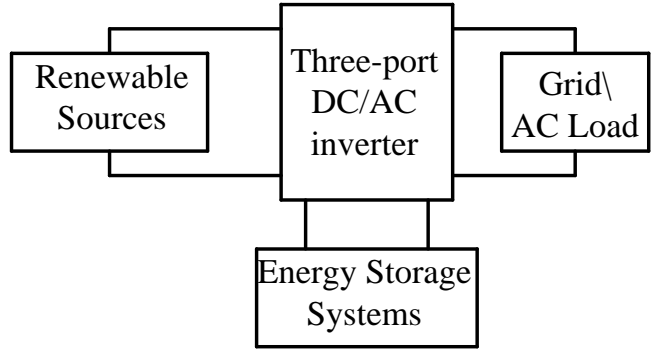

Fig. 39 The configuration of single-stage connection.

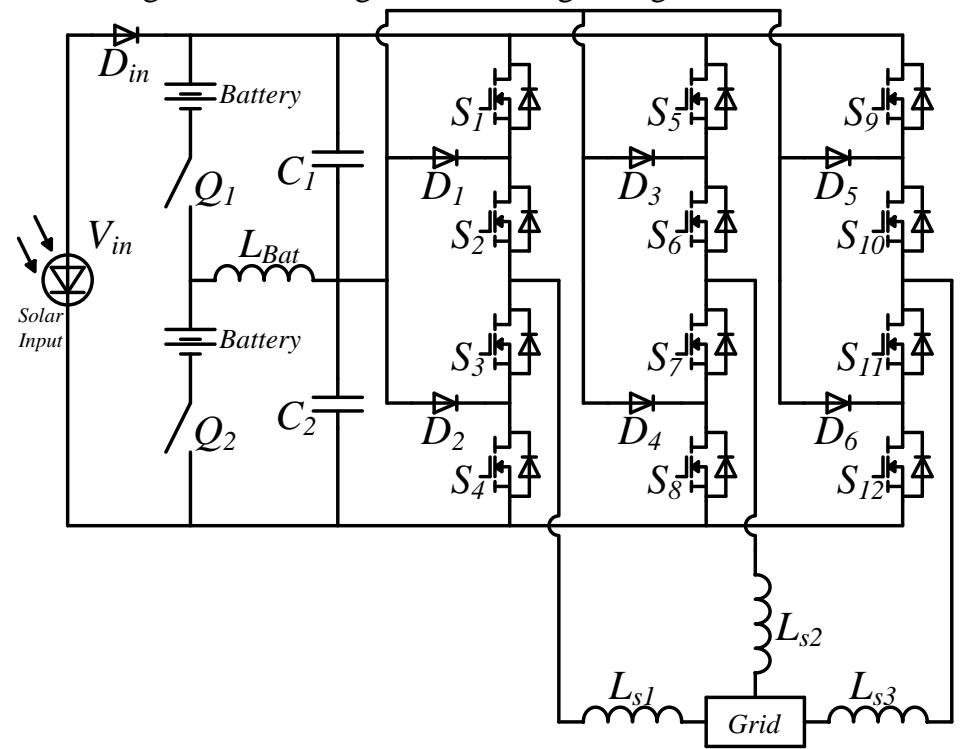

Fig. 40 The inverter proposed in [67].

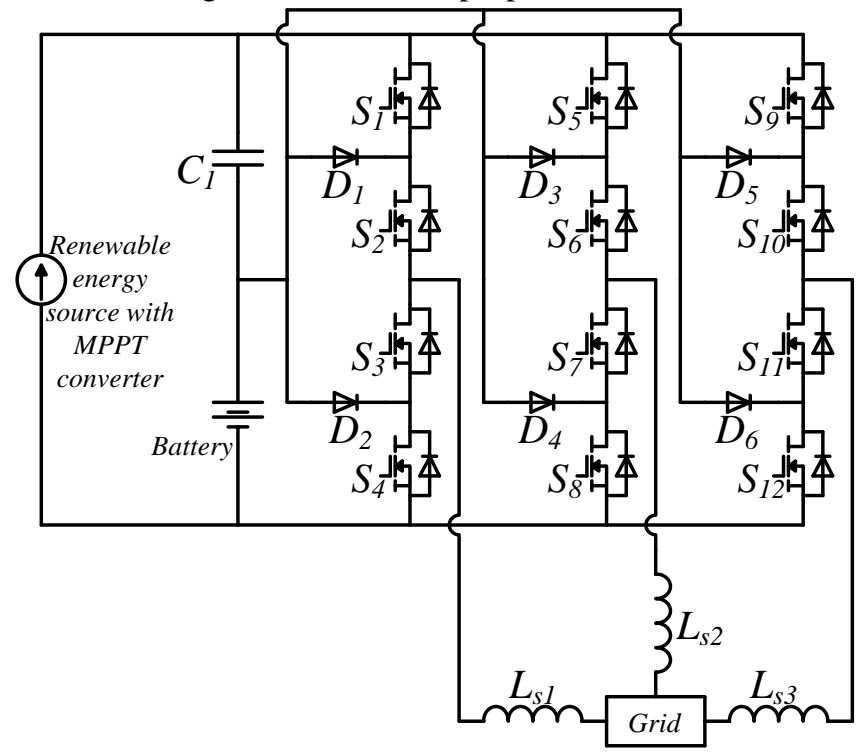

Fig. 41 The inverter proposed in [68]. 


\subsection{Z-Source based three-port inverters}

Z-source impedance network and its modifications, taking advantage of their inherent characteristics that includes two capacitors that can be used as energy storage systems, can be used to derive three-port DC-AC inverters.

By replacing one of the two capacitors in the Z-source impedance network with an energy storage system (e.g. a battery) and controlling the shoot through duty cycle and modulation index independently, a Z-source inverter can be converted to a three-port inverter easily as shown in Fig. 42 [69]. By connecting an energy storage system to one of the two capacitors in the quasi-Z-source impedance network in parallel, a new three-port inverter was first proposed in [70] as shown in Fig. 43. Following the introduction of this novel inverter, some control and modulation technologies for this inverter are proposed [71-74]. A modification of the inverter shown in Fig. 43 is proposed in [75] as shown in Fig. 44. However, all of these Z-source based three-port inverters are based on the traditional two-level three-phase inverter. The application of Z-source impedance network in other inverters such as the neutral-point-clamped three-level inverter and single phase inverters can be investigated further.

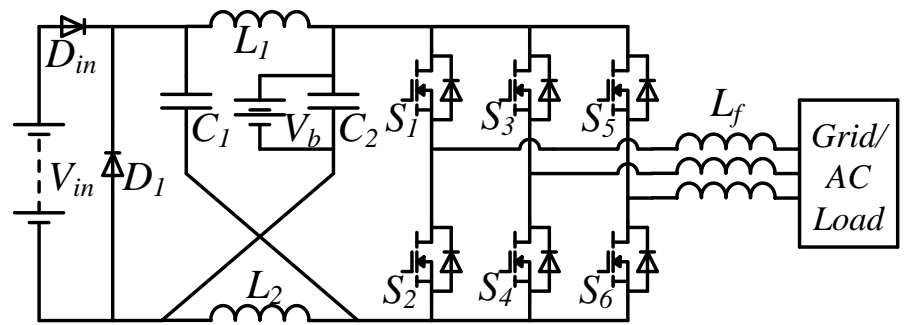

Fig. 42 The inverter proposed in [69].

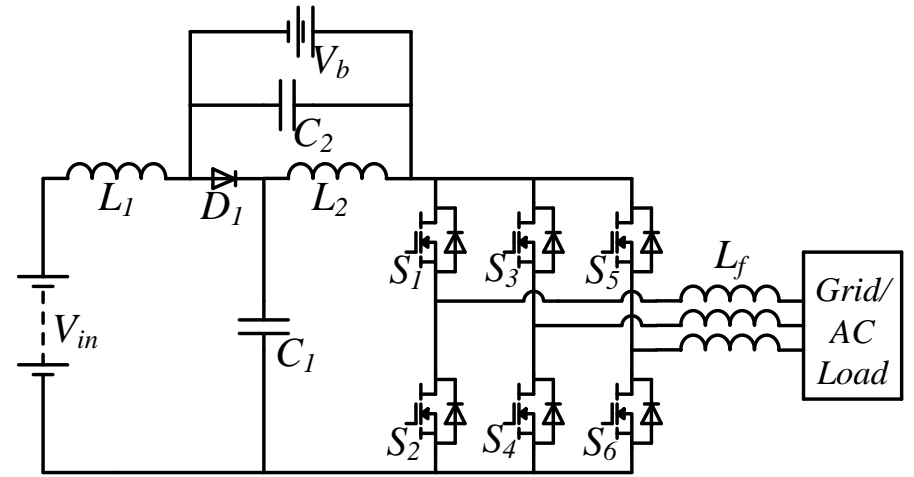

Fig. 43 The inverter proposed in [70].

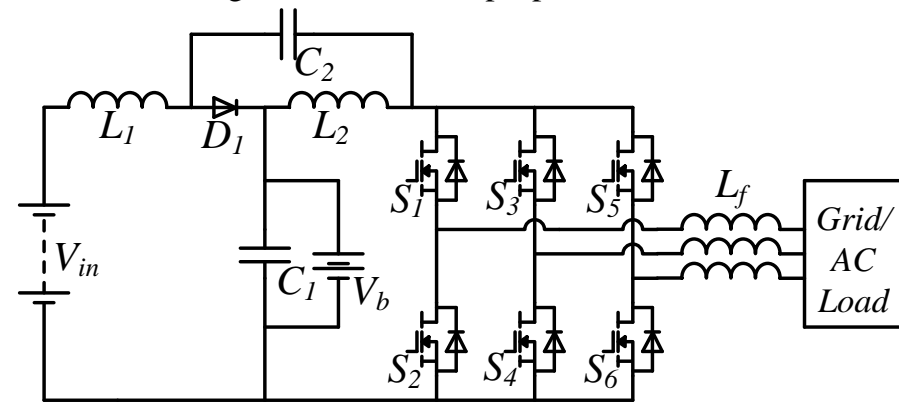

Fig. 44 The inverter proposed in [75].

\section{Conclusion}

This paper has provided a literature review of the topologies used for the three-port DC-DC converters. The review suggests that the research of three-port DC-DC converters has gained remarkable progress and has also gained increasing attention from researchers working in the area of integrating renewable energy and energy storage systems to overcome the intermittent nature of renewable energy resources. The general operation principles, advantages and disadvantages of different topologies of the three-port DC-DC converters are discussed. The three-port DC-DC converter techniques are generally superior to the traditional two-stage architecture of renewable energy and energy 
storage system in terms of efficiency, power density, size, and cost of the converter. The comparison of the three-port DC-DC converters proposed by different researchers has been carried out as a guide for the appropriate selection of converters for utilization in practical applications. In order to promote the wider use of three-port DC-DC converters in integrating renewable resources and energy storage systems, future research needs to be carried out to increase the voltage gain of the converter and to design novel three-port DC-AC inverters.

\section{Acknowledgement}

The first author acknowledges the China Scholarship Council and the University of Wollongong for supporting his PhD scholarship.

\section{References}

[1] Sinha S., Chandel S. S. Review of recent trends in optimization techniques for solar photovoltaic-wind based hybrid energy systems. Renewable Sustainable Energy Rev 2015; 50: 755-769.

[2] Rajesh R., Carolin Mabel M. A comprehensive review of photovoltaic systems. Renewable Sustainable Energy Rev 2015; 51: 231-248.

[3] Parida B., Iniyan S., Goic, R. A review of solar photovoltaic technologies. Renewable Sustainable Energy Rev 2011; 15 (3): 1625-1636.

[4] Hosenuzzaman M., Rahim N.A., Selvaraj J., Hasanuzzaman M., Malek A.B.M.A., Nahar A. Global prospects, progress, policies, and environmental impact of solar photovoltaic power generation. Renewable Sustainable Energy Rev 2015; 41: 284-297.

[5] Bhatnagar P., Nema R.K. Maximum power point tracking control techniques: State-of-the-art in photovoltaic applications. Renewable Sustainable Energy Rev 2013; 23: 224-241.

[6] Mirhassani S., Ong H.C., Chong W.T., Leong K.Y. Advances and challenges in grid tied photovoltaic systems. Renewable Sustainable Energy Rev 2015; 49: 121-131.

[7] Sun K., Zhang L., Xing Y., Guerrero J. M. A distributed control strategy based on dc bus signaling for modular photovoltaic generation system with battery energy storage. IEEE Transaction on Power Electronics 2011; 26 (10): 3032 - 3045.

[8] Locment F., Sechilariu M., Houssamo I. DC load and batteries control limitations for photovoltaic systems: experimental validation. IEEE Transaction on Power Electronics 2012; 27 (9): 4030 - 4038.

[9] Rehman Z., AI-Bahadly I., Mukhopadhyay S. Multiinput DC-DC converters in renewable energy applicatons-An overview. Renewable Sustainable Energy Rev 2015; 41: 521-539.

[10] Wu H., Sun K., Ding S., Xing Y. Topology derivation of non-isolated three-port DC-DC converters from DIC and DOC. IEEE Transactions on Power Electronics 2013; 28(7): 3297-3307.

[11] Wu H., Xing Y., Xia Y., Sun K. A family of non-isolated three-port converters for stand-alone renewable power system. In: IECON; 2011: 1030 - 1035.

[12] Ding S., Wu H., Xing Y., Fang Y., Ma X. Topology and control of a family of non-isolated three-port DC/DC converters with a bidirectional cell. In: APEC; 2013: 1089- 1094.

[13] Chen Y., Wen G., Peng L., Kang Y., J. Chen. A family of cost-efficient non-isolated single-inductor three-port converters for low power stand-alone renewable power applications. In: APEC; 2013: 1083 - 1088.

[14] Chen Y., Zhang P., Zou X., Kang Y. Dynamical modelling of the non-isolated single-inductor three-port converter. In: APEC; 2014: 2067 - 2073.

[15] Vazquez N., Sanchez C. M., Hernandez C., Vazquez E., Lesso R. A three-port converter for renewable energy applications. In: ISIE; 2011: 1735 - 1740.

[16] Zhou Z., Wu H., Ma X., Xing Y. A non-isolated three-port converter for stand-alone renewable power system. In: IECON; 2012: 3352 - 3357.

[17] Wen G., Chen Y., Kang Y. A Family of Cost-Efficient Integrated Single-Switch Three-Port Converters. In: APEC; 2013: 1062 - 1067.

[18] Zhu H., Zhang D., Zhang B., Zhou Z. A non-isolated three-port DC-DC converter and three-domain control method for PV-battery power systems. IEEE Transactions on Industrial Electronics 2015; 62(8): 4937-4947.

[19] Chen Y. M., Huang A. Q., Yu X. A high step-up three-port DC-DC converter for stand-alone PV/Battery power systems. IEEE Transaction on Power Electronics 2013; 28(11): 5049-5062.

[20] Chen Y. M., Yu X., Huang A. Q. A new non-isolated three-port DC/DC converter with high step-up/down ratio. In: ECCE; 2012: 1520 - 1526.

[21] Chien L. J., Chen C. C., Chen J. F., Hsieh Y. P. Novel three-port converter with high-voltage gain. IEEE Transactions on Power Electronics 2014; 29(9): 4693-4703.

[22] Tseng O. H., Chen J. F., Liang T. J., Liang H. W. A novel high step-up three-port converter. In: PEAC; $2014: 21$ 25. 
[23] Alves D. B. S., Praca P. P., Oliveira Jr. D. S., Barreto L. H. S. C., de Freitas L. C. G. A single-stage three-port boost converter with high voltage gain based on the bidirectional version of the three-state switching cell. In: APEC; 2015: 1934 - 1940.

[24] Zhang P., Chen Y., Zhou Z., Kang Y. The cost-efficient, common-ground, non-isolated three-port converter deduced from the single-inductor dual-output topology. In: APEC; 2015: 2020 - 2025.

[25] Qian Z., Rahman O. A., Al-Atrash H., Batarseh I. Modelling and control of three-port DC/DC converter interface for satellite applications. IEEE Transactions on Power Electronics 2010; 25(3): 637-649.

[26] Qian Z., Rahman O. A., Reese J., Atrash H. A., Batarseh I. Dynamic analysis of three-port DC/DC converter for space applications. In: APEC; 2009: 28 - 34.

[27] Qian Z., Rahman O. A., Pepper M., Batarseh I. Analysis and design for paralleled three-port DC/DC converters with democratic current sharing control. In: ECCE; 2009: 1375 - 1382.

[28] Qian Z., Rahman O. A., Hu H., Batarseh I. Multi-channel three-port DC/DC converters as maximum power tracker, battery charger and bus regulator. In: APEC; 2010: 2073 - 2079.

[29] Qian Z., Rahman O. A., Zhang K., Hu H., Shen J., Batarseh I. Design and analysis of three-port DC/DC converters for satellite platform power system. In: ECCE; 2011: 1454 - 1460.

[30] Wu H., Chen R., Zhang J., Xing Y., Hu H., Ge H. A family of three-port half-bridge converter for a stand-alone renewable power system. IEEE Transactions on Power Electronics 2011; 26(9): 2697-2706.

[31] Wu H., Xing Y., Chen R., Zhang J., Sun K., Ge H. A three-port half-bridge converter with synchronous rectification for renewable energy application. In: ECCE; 2011: 3343 - 3349.

[32] Zhang J., Wu H., Gao F., Xing Y., Ma X. Analysis and design of DC distributed DC power system with modular three-port converter. In: ISIE; 2014: 416 - 421.

[33] Wu H., Sun K., Chen R., Hu H., Xing Y. Full-bridge three-port converters with wide input voltage range for renewable power systems. IEEE Transactions on Power Electronics 2012; 27(9): 3965-3974.

[34] Parthiban R., Rajamnal K. Performance investigation of three-port converter for hybrid energy system. In: ICEES; 2014: 261 - 266.

[35] Sun X., Liu F., Xiong L., Wang B. Research on dual buck/boost integrated three-port bidirectional DC/DC converter. In: ITEC Asia-Pacific; 2014: 1 - 6.

[36] Sun X., Shen Y., Li W. A novel LLC integrated three-port DC-DC converter for stand-alone PV/battery system. In: ITEC Asia-Pacific; 2014: 1 - 6.

[37] Chen Z. Three-port ZVS converter with PWM plus secondary-side phase-shifted for photovoltaic-storage hybrid systems. In: APEC; 2014: 3066 - 3071.

[38] Qin X., Wu H., Zhang J., Xing Y. PWM+SSPS-controlled full-bridge three-port converter for aerospace power system. In: ITEC Asia-Pacific; 2014: 1 - 6.

[39] Wang Z., Li H. A integrated three-port bidirectional DC-DC converter for PV application on a DC distribution system. IEEE Transactions on Power Electronics 2013; 28(10): 4612-4624.

[40] Wang Z., Li H. Integrated MPPT and bidirectional battery charger for PV application using one multiphase interleaved three-port DC-DC converter. In: APEC; 2011: 295 - 300.

[41] Hu W., Wu H., Xing Y., Sun K. A full-bridge three-port converter for renewable energy application. In: APEC; 2014: 57- 62.

[42] Zeng J., Qiao W., Qu L. An isolated three-port bidirectional DC-DC converter for photovoltaic systems with energy storage. In: Industrial Application Society Annual Meeting; 2013: 1 - 8.

[43] Hu Y., Xiao W., Cao W., Li B., Morrow D. J. Three-port DC-DC converter for stand-alone photovoltaic systems. IEEE Transactions on Power Electronics 2015; 30(6): 3068-3076.

[44] Zeng J., Qiao W., Qu L. Modelling and control of a three-port DC-DC converter for PV-battery systems. In: APEC; 2015: 1768 - 1773.

[45] Chen Z., Wu Q., Li M., Xu Y., Wang Q. A three-port DC-DC converter with low frequency current ripple reduction technique. In: APEC; 2015: 2069 - 2074.

[46] Zhu H., Zhang D., Athab H. S., Wu B., Gu Y. PV isolated three-port converter and energy-balancing control method for PV-battery power supply applications. IEEE Transactions on Industrial Electronics 2015; 62(6): 35953606.

[47] Duarte J. L., Hendrix M., Simoes M. G. Three-port bidirectional converter for hybrid fuel cell system. IEEE Transactions on Power Electronics 2007; 22(2): 480-487.

[48] Zhao C., Round S. D., Kolar J. W. An isolated three-port bidirectional DC-DC converter with decoupled power flow management. IEEE Transactions on Power Electronics 2008; 23(5): 2443-2453.

[49] Oggier G. G., Botalla L. P., Garcia G. O. Soft-switching analysis for three-port bidirectional DC-DC converter. In: INDUSCON; 2010: 1 - 6.

[50] Botalla L. P., Oggier G. G., Airabella A. M., Garcia G. O. Analysis and evaluation of power switch losses for three-port bidirectional DC-DC converter. In: ICIT; 2012: 950 - 955.

[51] Botalla L. P., Oggier G. G., Airabella A. M., Garcia G. O. Power losses evaluation of a bidirectional three-port DC-DC converter for hybrid electric system. International Journal of Electrical Power and Energy Systems 2014; 58: $1-8$ 
[52] Phattanasak M., Ghoachani R. G., Martin J. P., Mobarakeh B. N., Pierfederici S., Davat B. Control of a hybrid energy source comprising a fuel cell and two storage devices using isolated three-port bidirectional DC-DC converters. IEEE Transactions on Power Electronics 2015; 51(1): 491-497.

[53] Jiang Y., Liu F., Ruan X., Wang L. Optimal idling control strategy for three-port full-bridge converter. In: ECCEASIA; 2014: 458 - 464.

[54] Kim S. Y., Song H. S., Nam K. Idling port isolation control of three-port bidirectional converter for EVs. IEEE Transactions on Power Electronics 2012; 27(5): 2495-2506.

[55] Phattanasak M., Ghoachani R. G., Martin J. P., Pierfederici S., Davat B. Flatness based control of an isolated threeport bidirectional DC-DC converter for a fuel cell hybrid source. In: ECCE; 2011: 977 - 984.

[56] Krishnaswami H., Mohan N. Three-port series-resonant DC-DC converter to interface renewable energy sources with bidirectional load and energy storage ports. IEEE Transactions on Power Electronics 2009; 24(10): 22892297.

[57] Falcones S., Ayyanar R. Simple control design for a three-port DC/DC converter based PV system with energy storage. In: APEC; 2010: 2149 - 2153.

[58] Tao H., Duarte J. L., Hendrix M. A. M. Three-port triple-half-bridge bidirectional converter with zero-voltage switching. IEEE Transactions on Power Electronics 2008; 23(2): 782-792.

[59] Wang L., Wang Z., Li H. Asymmetrical duty cycle control and decoupled power flow design of a three-port bidirectional DC-DC converter for fuel cell vehicle application. IEEE Transactions on Power Electronics 2012; 27(2): 891-904.

[60] Xie J., Zhang X., Zhang C. W., Liu S. Y. A novel three-port bidirectional DC/DC converter. In: PEDG; $2010: 717$ $-720$.

[61] Samavatian V., Bathaee S. M. T., Fereidunian A. Half-bridge current-fed multi-resonant bidirectional three-port DC converter for flexible distributed generation. In: PEDSTC; 2014: 172 - 176.

[62] Biswas S., Dhople S., Mohan N. A three-port bidirectional DC-DC converter with zero-ripple terminal currents for PV/microgrid applications. In: IECON; 2013: 340 - 345.

[63] Song Y., Wang B. Survey on reliability of power electronic systems. IEEE Transactions on Power Electronics 2013; 28(1): 591-604.

[64] Yang S., Bryant A., Mawby P., Xiang D., Ran L., Tavner P. An industry-based survey of reliability in power electronic converters. IEEE Transactions on Industrial Applications 2011; 47(3): 1441-1451.

[65] Li W., He X. Review of nonisolated high-step-up DC/DC converters in photovoltaic grid-connected applications. IEEE Transactions on Industrial Electronics 2011; 58(4): 1239-1250.

[66] Wu T.-F., Lai Y.-S., Hung J.-C., Chen Y.-M. Boost converter with coupled inductors and buck-boost type of active clamp. IEEE Transactions on Industrial Electronics 2008; 55(1): 154-162.

[67] Teymour H. R., Sutanto D., Muttaqi K. M., Ciufo P. Solar PV and battery storage integration using a new configuration of a three-level NPC inverter with advanced control strategy. IEEE Transactions on Energy Conversion 2014; 29(2): 354-365.

[68] Jayasinghe S. D. G., Vilathgamuwa D. M., Madawala U. K. Diode-clamped three-level inverter-based battery/supercapacitor direct integration scheme for renewable energy system. IEEE Transactions on Power Electronics 2011; 26(12): 3720-3729.

[69] Peng F. Z., Shen M., Holland K. Application of Z-source inverter for traction drive of fuel application of Z-source inverter for traction drive of fuel cell-battery hybrid electric vehicles. IEEE Transactions on Power Electronics 2007; 22(3): 1054-1061.

[70] Jorge G. C. R., Li Y., Jiang S., Peng F. Z. Quasi-Z-source inverter with energy storage for photovoltaic power generation systems. In: APEC; 2011: 401 - 406.

[71] Liu J., Jiang S., Cao D., Peng F. Z. A digital current control of quasi-Z-source inverter with battery. IEEE Transactions on Industrial Informatics 2013; 9(2): 928-937.

[72] Liu Y., Ge B., Haitham A. R., Peng F. Z. Control system design of battery-assisted quasi-Z-source inverter for grid-tie photovoltaic power generation. IEEE Transactions on Sustainable Energy 2013; 4(4): 994-1001.

[73] Haitham A. R., Iqbal A., Ahmed SK. M., Peng F. Z., Li Y., Ge B. Quasi-Z-source inverter-based photovoltaic generation system with maximum power tracking control using ANFIS. IEEE Transactions on Sustainable Energy 2013; 4(1): 11-20.

[74] Liu Y., Ge B., Haitham A. R., Peng F. Z. Modelling and controller design of quasi-Z-source inverter with batterybased photovoltaic power system. IET Power Electronics 2014; 7(7): 1665-1674.

[75] Ge B., Haitham A. R., Peng F. Z., Lei Q., Almeida A. T. de, Ferreira F. J. T. E., Sun D., Liu Y. An energy-stored quasi-Z-source inverter for application to photovoltaic power system. IEEE Transaction on Industrial Electronics 2013; 60(10): 4468-4481. 